\title{
Synthesis, Structure, and Activity of Diclofenac Analogues as Transthyretin Amyloid Fibril Formation Inhibitors
}

\author{
Vibha B. Oza, ${ }^{\dagger}, \#$ Craig Smith, ${ }^{\S, \#}$ Prakash Raman, ${ }^{\dagger}$ Edward K. Koepf, ${ }^{\dagger}$ Hilal A. Lashuel, ${ }^{\dagger}{ }^{H}$. Mike Petrassi, ${ }^{\dagger}$ \\ Kyle P. Chiang, ${ }^{\dagger}$ Evan T. Powers, ${ }^{\dagger} \mathrm{J}$ ames Sachettinni, ${ }^{\S}$ and J effery W. Kelly*,† \\ Department of Chemistry and The Skaggs Institute of Chemical Biology, The Scripps Research Institute, \\ 10550 North Torrey Pines Road, BCC 265, La J olla, California 92037, and Department of Biochemistry and Biophysics, \\ Texas A \& M Univeristy, College Station, Texas 77843-3255
}

Received J une 11, 2001

Twelve anal ogues of dicl ofenac (1), a nonsteroidal antiinflammatory drug and known inhibitor of transthyretin (TTR) amyloid formation, were prepared and evaluated as TTR amyloid formation inhibitors. High activity was exhi bited by five of the compounds. Structure-activity relationships reveal that a carboxylic acid is required for activity, but changes in its position as well as the positions of other substituents are tolerated. High-resolution X-ray crystal structures of four of the active compounds bound to TTR were obtained. These demonstrate the significant flexibility with which TTR can accommodate ligands within its two binding sites.

\section{Introduction}

Transthyretin (TTR) is a tetrameric protein made up of four identical $\beta$-sheet sandwich subunits, each composed of 127 amino acids. ${ }^{1,2}$ TTR is present at a concentration of approximately $0.2 \mathrm{mg} / \mathrm{mL}(3.6 \mu \mathrm{M})$ in human plasma, ${ }^{3,4}$ where it is a secondary carrier of the thyroid hormone thyroxine (thyroid binding globulin being the primary carrier $)^{3,5}$ and the sole transporter of the retinol binding protein-vitamin A complex. ${ }^{6}$ In cerebrospinal fluid it is present at approximately 10fold lower concentration ${ }^{4}$ and is the primary carrier of thyroxine. ${ }^{7}$ Under acidic conditions, like those found in cellular organelles such as the lysosome, TTR dissociates to an alternatively folded, monomeric intermediate that self-assembles into amyl oid fibrils. ${ }^{8-12}$ The deposition of wild type TTR amyloid has been implicated to cause the disease senile systemic amyloidosis (SSA), whereas the deposition mutant TTR amyloid has been implicated to cause the diseases familial amyloid cardiomyopathy (FAC) and familial amyloid polyneuropathy (FAP); over 80 variants of TTR have been associated with FAC and FAP. ${ }^{13,14}$ SSA involves the deposition of amyloid in the heart, with symptoms typically appearing around ages 70 to $80 .{ }^{15} \mathrm{FAP}$ and FAC involve the deposition of amyloid in either the peripheral nerves (FAP) or the heart (FAC), with symptoms typically appearing much earlier than in SSA. ${ }^{14,16}$ The most prevalent form of FAP is associated with the V30M variant of TTR, with disease onset occurring in the mid30 s to early 40 s. $^{13,14}$ The most severe form of FAP is associated with the L55P variant of TTR, with disease onset occurring in the second decade of life. ${ }^{17} \mathrm{~A}$ comparison of the X-ray crystal structures of wild type, V30M, and L55P TTR does not reveal any differences

* To whom correspondence should be addressed. Tel: 858-784-9605. Fax: 858-784-9610. E-mail: jkelly@scripps.edu.

\# These authors contributed equally to this work.

† The Scripps Research Institute.

$\S$ Texas A \& M Univeristy. that can explain the amyloidogenicities of the latter two variants, ${ }^{18}$ nor is the function of the variants noticeably compromised. All evidence suggests that these are gain of toxic function diseases associated with the process of amyloid fibril formation. Consistent with this, L55P TTR is markedly less stable to acid-induced tetramer dissociation and amyloid formation than V30M TTR, which is in turn less stable than wild type TTR. ${ }^{11,19-21}$ Thus, for these three variants, the ages of onset of TTR amyloid diseases correlate directly with the acid stabilities of the TTR tetramers involved.

The only treatment for FAP that has proven successful is liver transplantation, a form of gene therapy in which the mutant gene is replaced with the wild type in the organ that secretes the protein into the plasma. ${ }^{22}$ While this demonstrates that TTR amyloid diseases can be treated by removing the amyloidogenic protein, it is severely limited by the availability of livers for transplantation and the requirement for lifelong immune suppression. A therapy in which a small molecule drug inhibits TTR amyloid formation would be preferable. Evidence that such an approach might be feasible comes from a simple observation: amyloid formation by TTR is very rare in tissues bathed by the cerebrospinal fluid ${ }^{23}$ where TTR is the primary carrier for thyroxine. ${ }^{7}$ This is even true in heterozygous FAP patients. Experiments have shown that the binding of thyroxine by TTR stabilizes the tetrameric state against acid induced dissociation, thus preventing amyloid formation in vitro. ${ }^{24}$

Because of its hormone activity, thyroxine cannot be used to inhibit TTR fibril formation in vivo. However, focused screening and rational design efforts have resulted in the identification of several structurally diverse small molecules that, like thyroxine, bind to and stabilize TTR under fibrillogenic conditions. ${ }^{25-30}$ The active structural classes include biaryls, ${ }^{26}$ flavones, ${ }^{26}$ phenoxazines, ${ }^{29}$ and diarylamines. ${ }^{26-28}$ In particular, the diarylamine dicl ofenac (1; also known as Voltaren), 
whose structure is shown bel ow, is a promising starting point for the preparation of a series of analogues that could be used for the treatment of TTR amyloidosis because (1) the parent compound is among the most active fibril formation inhibitors found to date; 27,30 (2) the diarylamine scaffold can be easily prepared with a wide variety of substituents; and (3) the parent compound has been approved by the FDA as a nonsteroidal antiinflammatory drug (NSAID), ${ }^{31}$ indicating that its analogues are likely to have suitable pharmacological properties.

Here we describe the design, preparation, fibril inhibition activity, and TTR cocrystal structures of a number of diclofenac (1) analogues. The information gained from these studies is used to develop an understanding of the structure-activity relationships that govern the efficacy of these compounds as inhibitors of TTR fibril formation.<smiles>O=C(O)Cc1ccccc1Nc1c(Cl)cccc1Cl</smiles>

Diclofenac (1)

\section{Binding and Activity of Diclofenac (1)}

The TTR homotetramer has 222 symmetry (that is, three perpendicular $\mathrm{C}_{2}$ symmetry axes), with two funnel shaped, $\mathrm{C}_{2}$-interconvertable binding sites located at the dimer-dimer interface. ${ }^{32}$ Each binding site can be divided into an inner and an outer cavity, which are further defined by three symmetry related pairs of binding pockets. These pockets historically have been referred to as the halogen binding pockets (HBP) because they accommodate the iodines of thyroxine. 32,33 HBP 1 and $1^{\prime}$ are in the outer cavity, HBP 2 and $2^{\prime}$ are at the interface between the inner and outer cavities, and HBP 3 and $3^{\prime}$ are in the inner cavity. The cocrystal structures of a diverse set of small molecules bound to TTR have been solved and reported. 25,29,30,33-37 Many of these, like dicl ofenac (1), consist of two aromatic rings separated by a spacer, with one of the rings bearing a carboxylate. $25,29,30$ Such compounds usually bind to TTR in what is referred to as the "forward mode", in which the carboxylate bearing ring occupies the outer binding cavity. The carboxylate is placed at the periphery of the cavity, allowing it to make electrostatic interactions with the $\epsilon-\mathrm{NH}_{3}{ }^{+}$groups of Lys 15 and $15^{\prime}$. This is exemplified by the binding of flufenamic acid, as shown in Figure 1 (both symmetry related binding modes are shown, one in green and the other in yellow). ${ }^{25}$

In striking contrast, diclofenac (1) binds in what is referred to as the "reverse mode" (Figure 2). ${ }^{30}$ In the binding mode shown in yellow, the 2-ethanoic acid substituted ring of diclofenac (1) occupies the inner binding cavity where the carboxylic acid forms a hydrogen bond with the $\gamma-\mathrm{OH}$ of Thr 119. Across the binding site, a $120^{\circ}$ rotation of the Thr $119^{\prime}$ side chain allows the hydrophobic portion of the 2-ethanoic acid substituted ring to fill HBP 3'. The 2,6-dichloro substituted ring occupies the outer binding cavity where the $\mathrm{C} 3, \mathrm{C} 4$, and $\mathrm{C} 5$ portion of the ring fill HBP 1 , interacting with

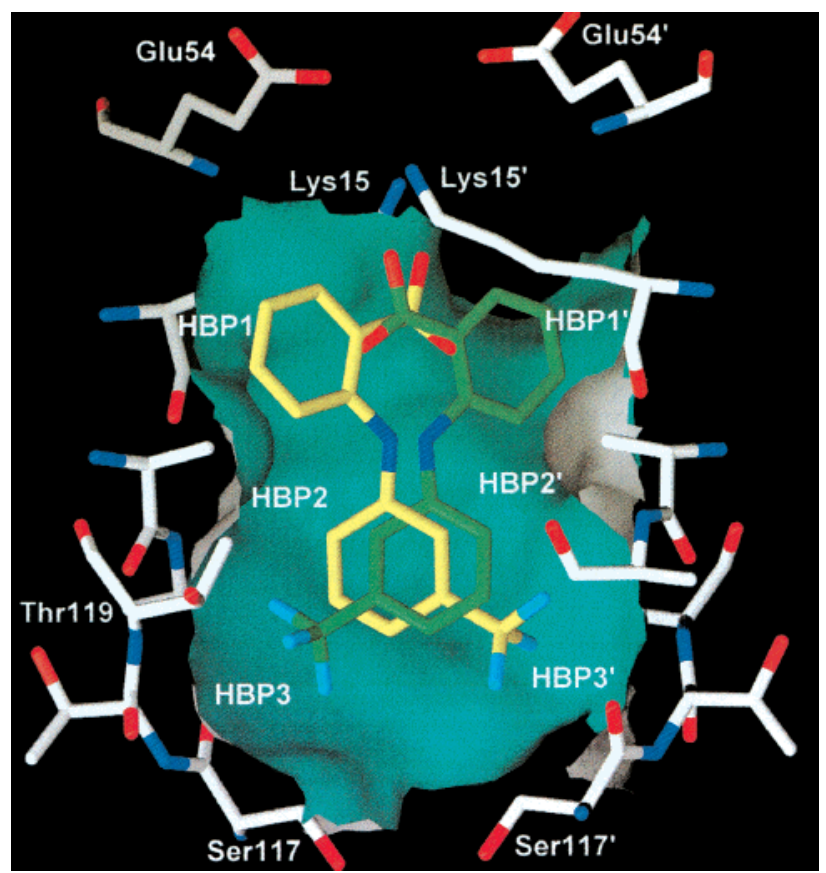

Figure 1. Flufenamic acid bound to TTR in the forward binding mode, with its carboxylic acid interacting with the $\epsilon-\mathrm{NH}_{3}{ }^{+}$of Lys 15 . The two symmetry related binding modes are shown in green and yellow. Unprimed and primed residue numbers or HBPs refer to residues or HBPs in different but symmetry related monomers in the TTR tetramer. The surface of the binding site is shown in blue (view from interior) and gray (view from exterior).

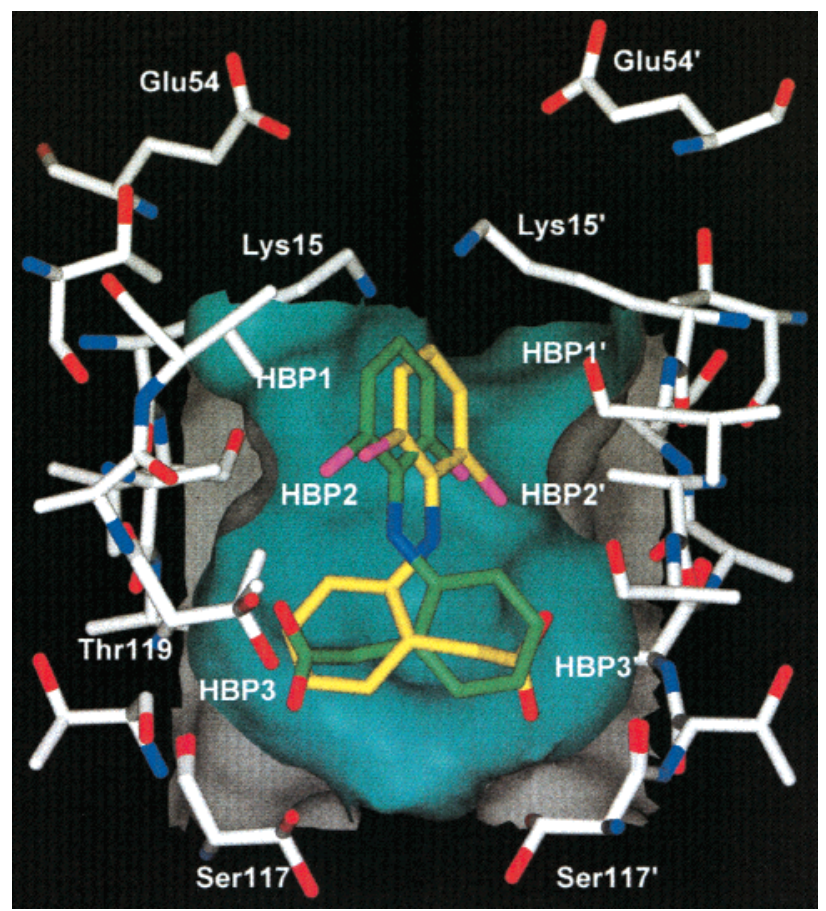

Figure 2. Diclofenac (1) bound to TTR in the reverse mode, with its carboxylic acid interacting with the $\gamma-\mathrm{OH}$ of Thr 119. As above, the two symmetry related binding modes are shown in green and yellow, and the binding site's surface is shown in blue (view from interior) and gray (view from exterior).

the side chains of Leu 17, Ala 108, Val 121, and the $\gamma$-methyl group of Thr 119. The chlorine substituents fill HBP 2 and 2 ' at the interface between the inner and outer binding cavities. 
Table 1. First $\left(\mathrm{K}_{\mathrm{d} 1}\right)$ and Second $\left(\mathrm{K}_{\mathrm{d} 2}\right)$ Dissociation Constants of the Binding of Diclofenac (1) to Wild Type, V30M, and L55P TTR Determined by I sothermal Titration Calorimetry

\begin{tabular}{lcl}
\hline protein & $\mathrm{K}_{\mathrm{d} 1}(\mathrm{nM})$ & $\mathrm{K}_{\mathrm{d} 2}(\mathrm{nM})$ \\
\hline wild type & $60 \pm 30$ & $1200 \pm 860$ \\
V30M & $160 \pm 70$ & $3900 \pm 730$ \\
L55P & $380 \pm 190$ & $6180 \pm 1300$ \\
\hline
\end{tabular}

While didlofenac (1) (and some of its analogues studied in this work; see below) is the only TTR fibril formation inhibitor studied to date that has been shown to bind in the reverse mode, 25,29,30 it still exhibits binding affinity and fibril inhibition activity comparable to the most active inhibitors that bind in the forward mode. Diclofenac's (1) binding to wild type, V30M, and L55P TTR was characterized by isothermal titration calorimetry, and the dissociation constants are listed in Table 1. The first dissociation constants are 15-20-fold lower than the second dissociation constants in every case, indicating that dicl ofenac (1) binds with negative cooperativity (which is typical for the binding of small molecules to TTR). Diclofenac's (1) dissociation constants to the various TTR variants are comparable to those of flufenamic acid, the benchmark for TTR fibril formation inhibitors. ${ }^{25}$

The activity of diclofenac (1) as a fibril formation inhibitor was measured previously against wild type TTR. ${ }^{27,30} \mathrm{Fibril}$ formation after $72 \mathrm{~h}$ of incubation at $\mathrm{pH}$ 4.4 (enough time to reach the plateau phase for TTR amyloid fibril formation) was reduced by $65 \%$ at a diclofenac (1) concentration sufficient to load one of the two TTR binding sites. At a concentration sufficient to load both of the binding sites, fibril formation was reduced by $83 \%$ (compare to reductions of $74 \%$ and $97 \%$ for flufenamic acid at the same concentrations). ${ }^{25,29}$

\section{Design of Analogues}

To probe how the display of functional groups on diclofenac's (1) diarylamine scaffold relates to its fibril inhibition activity and unique binding mode, the analogues shown in Figure 3 were prepared and assayed. In several cases, their cocrystal structures with TTR were determined. The importance of didlofenac's (1) 2-ethanoic acid functional group as a hydrogen bond acceptor for the hydroxyl of Thr 119 was examined using analogues 2-5, in which this substituent has been modified. In $\mathbf{2}$ and $\mathbf{3}$ the acid has been replaced by a methyl ester and an alcohol respectively, functional groups that have only modest potency as hydrogen bond acceptors. ${ }^{38}$ The primary amide in $\mathbf{4}$ is a much stronger hydrogen bond acceptor than an ester or an alcohol,38 but it is weaker than a charged carboxylate. The 2-methanoic acid in $\mathbf{5}$ retains the carboxylic acid functionality, but eliminates the aliphatic spacer between it and the aryl ring. The importance of having a polar functional group to interact with the residues that line the inner binding cavity was evaluated using 6-9. In these diclofenac (1) analogues, the 2-ethanoic acid functionality was replaced by chloroethyl, ethyl, isopropyl, and propyl groups, respectively. The importance of the 2,6-dichloro substitution pattern in $\mathbf{1}$ and $\mathbf{5}$ was examined using $\mathbf{1 0}$ and $\mathbf{1 1}$, in which the chlorines were moved from the 2 and 6 positions to the 3 and 5
Inhibitors with Modified 2-Ethanoic Acid<smiles>COC(=O)Cc1ccccc1Nc1c(Cl)cccc1Cl</smiles>

2<smiles>NC(=O)Cc1ccccc1Nc1c(Cl)cccc1Cl</smiles>

4<smiles>OCCc1ccccc1Nc1c(Cl)cccc1Cl</smiles>

3<smiles>O=C(O)c1ccccc1Nc1c(Cl)cccc1Cl</smiles>

5
Inhibitors with 2-Ethanoic Acid Replaced by Hydrophobic Groups<smiles>ClCCc1ccccc1Nc1c(Cl)cccc1Cl</smiles>

6

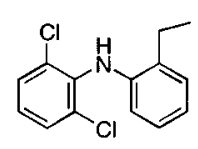

7

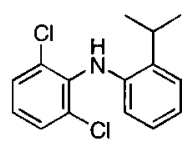

8<smiles>CCCc1ccccc1Nc1c(Cl)cccc1Cl</smiles>

9
Inhibitors with 3,5-Dichloro Substituted Ring<smiles>O=C(O)Cc1ccccc1Nc1cc(Cl)cc(Cl)c1</smiles><smiles>O=C(O)c1ccccc1Nc1cc(Cl)cc(Cl)c1</smiles>

Inhibitors with 2,6-Dichloro-4-Carboxylic Acid Substituted Ring<smiles>O=C(O)Cc1ccccc1Nc1c(Cl)cc(C(=O)O)cc1Cl</smiles>

12<smiles>O=C(O)c1cc(Cl)c(Nc2ccc([N+](=O)[O-])cc2)c(Cl)c1</smiles>

13
Figure 3. Analogues of diclofenac (1) prepared for this study.

positions. The effect of placing a carboxylate in the 4 position of the 2,6-dichloro substituted ring while retaining the 2-ethanoic acid group on the other was evaluated using 12. The 4-carboxylate was envisioned to form an electrostatic interaction with the Lys 15 and $15^{\prime} \epsilon-\mathrm{NH}_{3}{ }^{+}$groups if it bound in the same orientation as diclofenac (1). Finally, analogue $\mathbf{1 3}$ was prepared to determine the effect of having a negatively charged substituent only on the dichloro-substituted ring. The 4-nitro group on the other ring was required for ease of synthesis (see below).

\section{Results}

Synthesis of Diclofenac (1) Analogues. A number of the compounds shown in Figure 3 have been prepared and studied previously $\left(\mathbf{2}, 393,{ }^{30,41} \mathbf{4},{ }^{39} \mathbf{5},{ }^{42-46} \mathbf{1 0},{ }^{47}\right.$ and $\mathbf{1 1}^{42-45,48}$ ) to evaluate their activities as antiinflammatories, analgesics, etc. Synthetic details are reported here only when our procedures differ significantly from those al ready reported.

Analogues 2-4 in which the 2-ethanoic acid substituent is modified were prepared starting from the commercially available sodium salt of diclofenac (1), as shown in Scheme 1. The free acid was obtained by dissolution of the sodium salt in water followed by acidification and extraction. Treatment with trimethyl- 
Scheme 1. Synthesis of 2, 3, 4, and 6 from Didofenac

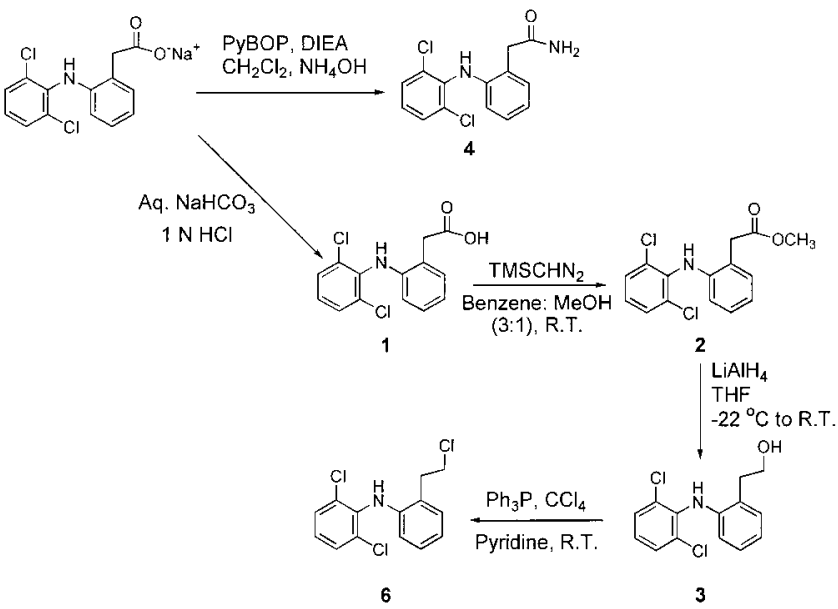

silyldiazomethane yiel ded the methyl ester $\mathbf{2}$, which was in turn converted to alcohol $\mathbf{3}$ by reduction with $\mathrm{LiAlH}_{4}$. The primary amide $\mathbf{4}$ was obtained directly from the sodium salt of diclofenac (1) by activation with PyBOP followed by addition of $\mathrm{NH}_{4} \mathrm{OH}$. The 2-methanoic acid analogue, 5, is a known compound and was prepared as described by Chalmers et al. ${ }^{42}$

The members of the remaining three groups of analogues displayed in Figure 3 were prepared by coupling anilines with aryl halides or triflates (except for alkyl chloride 6, which was prepared by $\mathrm{CCl}_{4}-\mathrm{PPh}_{3}$ reaction with al cohol 3;49 see Scheme 1). For $\mathbf{7 , ~ 8 , ~ 9 , ~ 1 1 , ~}$ and $\mathbf{1 3}$, the necessary coupling was accomplished using the palladium coupling chemistry developed by Buchwald ${ }^{50}$ and $\mathrm{H}$ artwig. ${ }^{51}$ The anilines listed in Scheme $2 a$ were coupled to the necessary aryl halides or triflates in refluxing toluene using the $\mathrm{Pd}_{2}(\mathrm{dba})_{3} /$ racemic $\mathrm{BINAP}$ catalyst and $\mathrm{CS}_{2} \mathrm{CO}_{3}$ as a base in $47-85 \%$ yield. The esters of $\mathbf{1 1}$ and $\mathbf{1 3}$ were hydrolyzed using $\mathrm{LiOH}$ in THF : $\mathrm{MeOH}: \mathrm{H}_{2} \mathrm{O}(3: 1: 1)$.

The $\mathrm{Pd}$-mediated coupling reaction failed when used for the preparation of $\mathbf{1 0}$ and $\mathbf{1 2}$, yielding either unreacted starting materials (10) or a complex mixture (12). Compound $\mathbf{1 0}$ had been prepared previously using the copper-mediated UIIman reaction. ${ }^{47}$ This procedure successfully yielded $\mathbf{1 0}$ and was adapted for the synthesis of $\mathbf{1 2}$ as shown in Scheme 2b. The anilines listed in Scheme 2b were coupled to N,N-dimethyl-2-iodoacetamide in refluxing toluene in the presence of $\mathrm{Cul}$, activated $\mathrm{Cu}$, and anhydrous $\mathrm{K}_{2} \mathrm{CO}_{3}$, yielding $\mathbf{1 0}$ and 12 as their dimethylamide protected derivatives. These were hydrol yzed to the corresponding acids using $\mathrm{KOH}$ in refluxing ethanol. $\mathrm{N}, \mathrm{N}$-Dimethyl-2-iodoacetamide was prepared by treating 2-iodophenylacetic acid with HBTU in the presence of dimethylamine hydrochloride and triethylamine.

Inhibitory Activities of 2-13. The activities of dicl ofenac (1) anal ogues 2-13 as inhibitors of wild type, V30M, and L55P TTR fibril formation under conditions that simulate those found in the lysosome were determined using a stagnant fibril formation assay. ${ }^{9,24}$ In this assay, the compound under evaluation is first incubated for 30 min with TTR at neutral $\mathrm{pH}\left(37^{\circ} \mathrm{C}\right)$. The $\mathrm{pH}$ is then lowered to give the maximal rate of fibril formation for a given variant (4.2 for wild type or 5.0 for $V 30 \mathrm{M}$ and L55P), and the samples are incubated for $72 \mathrm{~h}$ at
Scheme 2. (a) Synthesis of 7-9, 11, and $\mathbf{1 3}$ by the Palladium Catalyzed Coupling of Anilines with Aryl Halides or Triflates and (b) Synthesis of $\mathbf{1 0}$ and $\mathbf{1 2}$ by the Copper-Mediated UIIman Reaction
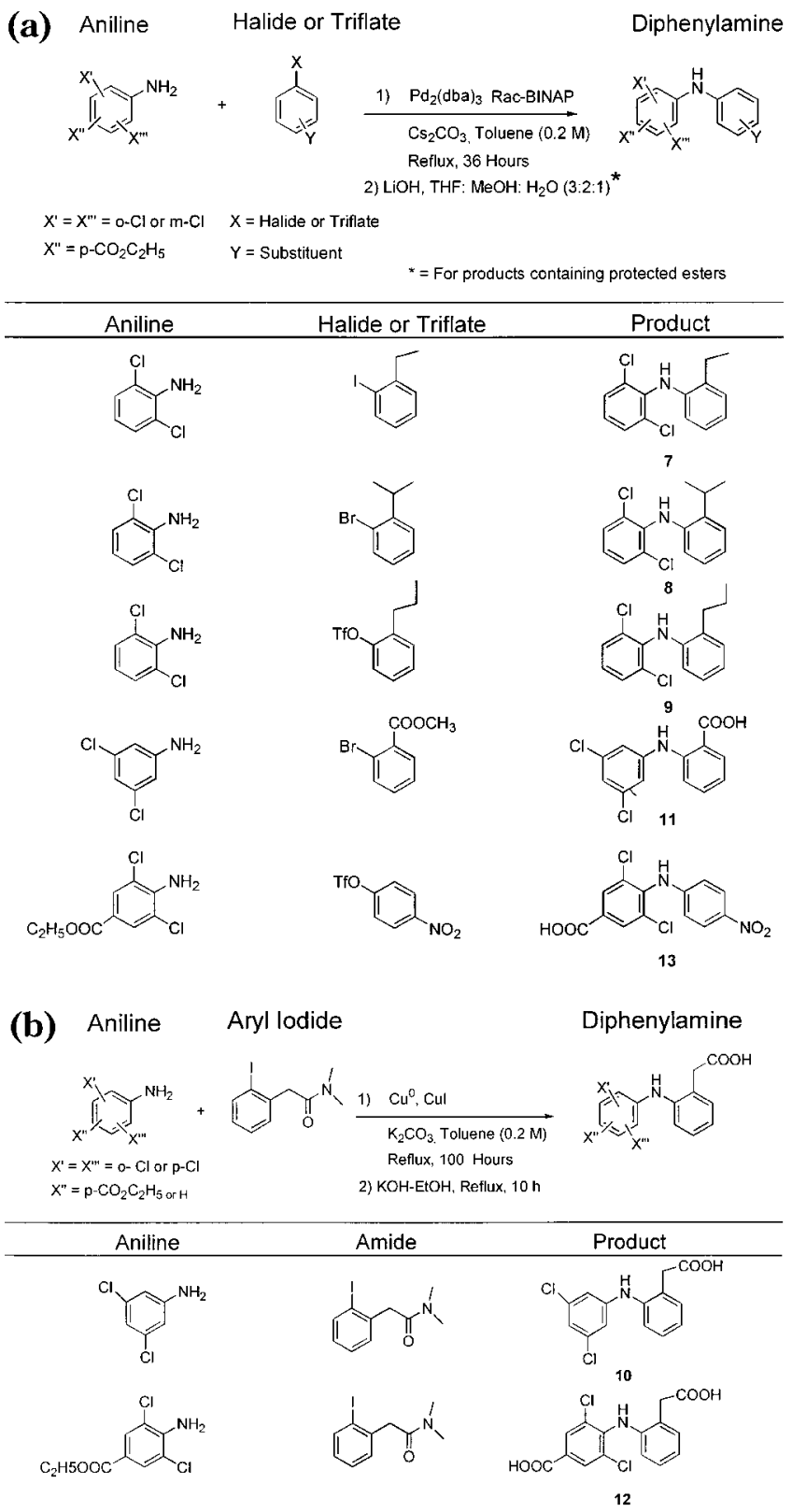

$37{ }^{\circ} \mathrm{C}$. The extent of fibril formation in the sample of interest is determined by comparing its turbidity at 400 $\mathrm{nm}$ to that of a sample of TTR in the absence of any test compound. The ratio of the turbidities of the samples with and without inhibitor multiplied by $100 \%$ gives the percent fibril formation, or \% FF, that characterizes the test compound's activity. A low \% FF (e.g., $4 \%$ FF) corresponds to high inhibitory activity $(96 \%$ inhibition). The efficacies of compounds $\mathbf{2}-\mathbf{1 3}$ in terms of $\% \mathrm{FF}$ are summarized in Table 2 . A limiting amount of test compound per equivalent of TTR tetramer was used, such that only one of TTR's two binding sites could be occupied. This was done so that the inhibitory activities would be measured under the most stringent conditions.

With one equivalent of inhibitor bound per equival ent of TTR tetramer, a \% FF of $40 \%$ or less indicates high 
Table 2. Percent Fibril Formation (\% FF) Data for Compounds 2-13 against Wild Type, V30M, and L55P TTRa

\begin{tabular}{|c|c|c|c|c|}
\hline & \multirow[t]{2}{*}{ Structure } & \multicolumn{3}{|c|}{$\%$ Fibril Formation Data at OD 400} \\
\hline & & WT & V30M & L55P \\
\hline 1 & & 35 & 33 & 72 \\
\hline 2 & & 78 & 90 & 90 \\
\hline 3 & & 60 & 62 & 90 \\
\hline 4 & & 65 & 67 & - \\
\hline 5 & & 30 & 27 & - \\
\hline 6 & & 75 & 70 & 90 \\
\hline 7 & & 82 & 70 & 85 \\
\hline 8 & & 85 & 80 & 90 \\
\hline 9 & & 100 & 85 & 90 \\
\hline 10 & & 30 & 27 & 53 \\
\hline 11 & & 34 & 30 & 50 \\
\hline 12 & & 32 & 28 & 45 \\
\hline 13 & & 40 & 33 & 75 \\
\hline
\end{tabular}

a The error in these assays is $\pm 5 \%$.

activity, a \% FF between $40 \%$ and $70 \%$ indicates modest activity, and a \% FF greater than $70 \%$ indicates weak activity. ${ }^{24-29}$

To ensure that these compounds inhibit TTR fibril formation by tetramer stabilization, the quaternary structures of wild type, V30M, and L55P TTR were evaluated by analytical ultracentrifugation in the presence of 10, 12, and $\mathbf{1 3}$ ( 3 equiv) at the $\mathrm{pH}$ maximum for fibril formation. The tetramer was the dominant species in all cases, and in only one case (L55P TTR with 10) did larger aggregates make up more than $10 \%$ of the total amount of protein detected (see Table 3).
Table 3. Quaternary Structure of the Soluble Protein after Incubation of $3.6 \mu \mathrm{M}$ Wild Type, V30M, and L55P TTR with $10.8 \mu \mathrm{M}$ of $\mathbf{1 0}, \mathbf{1 2}$, and $\mathbf{1 3}$ under Fibril Formation Conditions for $72 \mathrm{~h}$

\begin{tabular}{clcccc}
\hline compd & protein & $\begin{array}{c}\% \\
\text { tetramer }\end{array}$ & $\begin{array}{c}\% \\
\text { monomer }\end{array}$ & $\begin{array}{c}\% \\
\text { aggregate }\end{array}$ & $\begin{array}{c}\text { MW } \\
(\mathrm{kDa})\end{array}$ \\
\hline $\mathbf{1 0}$ & wild type & $>95$ & & & 55 \\
& V30M & $>95$ & & & 55 \\
& L55P & 76 & & 24 & 55 \\
\multirow{1}{12}{} & wild type & 95 & 5 & & 50 \\
& V30M & $>95$ & & & 53 \\
& L55P & $>95$ & & & 49 \\
\multirow{1}{13}{} & wild type & 93 & & 7 & $53-56$ \\
& V30M & 90 & & 10 & 47 \\
& L55P & $>95$ & & & $49-55$ \\
\hline
\end{tabular}

Crystal Structures of Inhibitors Bound to TTR. Cocrystals of did ofenac (1) analogues 10, 11, 12, and 13 bound to wild type TTR were obtained by soaking TTR crystals with a 10-fold excess of inhibitor for four weeks. ${ }^{25,30} \mathrm{High}$-resolution $\mathrm{X}$-ray structures, depicted in Figures 4-7, were then solved for each of these. Two symmetry related binding modes were observed in all cases because of the $\mathrm{C}_{2}$ axis of symmetry running through the center of the binding site. The inhibitors all bind in conformations that resemble their minimum energy conformations, as determined by molecular mechanics minimizations using the program Insight II (Molecular Simulations Inc.). The unique features of each structure are described below. Note that primed and unprimed residue numbers refer to residues that are interconverted by rotation about the $C_{2}$ axis of symmetry mentioned above.

(a) Compound 10 Bound to TTR. Compound 10 differs from diclofenac (1) only in that its chlorine substituents are in the 3 and 5 positions rather than the 2 and 6 positions. This similarity in structure leads to a similarity in the ways that $\mathbf{1 0}$ and diclofenac (1) bind: both bind in the reverse mode, and although $\mathbf{1 0}$ penetrates approximately $1 \AA$ deeper into the binding site, the interactions between it and TTR are similar to those observed for diclofenac (1). In the binding mode shown in yellow in Figure 4, the hydroxyl groups of Ser 117 and Thr 119 are rotated toward 10, making HBP 3 relatively hydrophilic. A hydrogen bond forms between the carboxyl of $\mathbf{1 0}$ and the $\gamma-\mathrm{OH}$ of Thr 119. The ring fills the more hydrophobic HBP 3 ' on the other side of the cavity. The 3,5-dichloro substituted ring occupies the outer cavity. The 3,5 substitution pattern allows the two chlorine atoms to fill HBP 1 and $1^{\prime}$, rather than 2 and 2 ' as in diclofenac (1). The aromatic ring interacts with the side chains of Leu 17 and Ala 108, and the aliphatic portion of the Lys 15 side chain. In particular, the interactions between the Lys $\gamma$ - and $\delta$-carbons force the $\epsilon-\mathrm{NH}_{3}{ }^{+}$into a position to form a salt bridge with the $\delta$ - $\mathrm{COO}^{-}$of Glu 54, an interaction that is not observed with diclofenac (1).

(b) Compound 11 Bound to TTR. Compound 11 differs from diclofenac (1) both in the 3,5-dichloro substitution pattern on one ring and in the presence of a 2-methanoic instead of a 2-ethanoic acid substituent on the other. These modifications do not, however, cause $\mathbf{1 1}$ to abandon the reverse binding mode. Figure 5 demonstrates that the carboxylic acid bearing aromatic ring still occupies the inner cavity, where it is able to hydrogen bond to the hydroxyls of both Ser 117 and Thr 


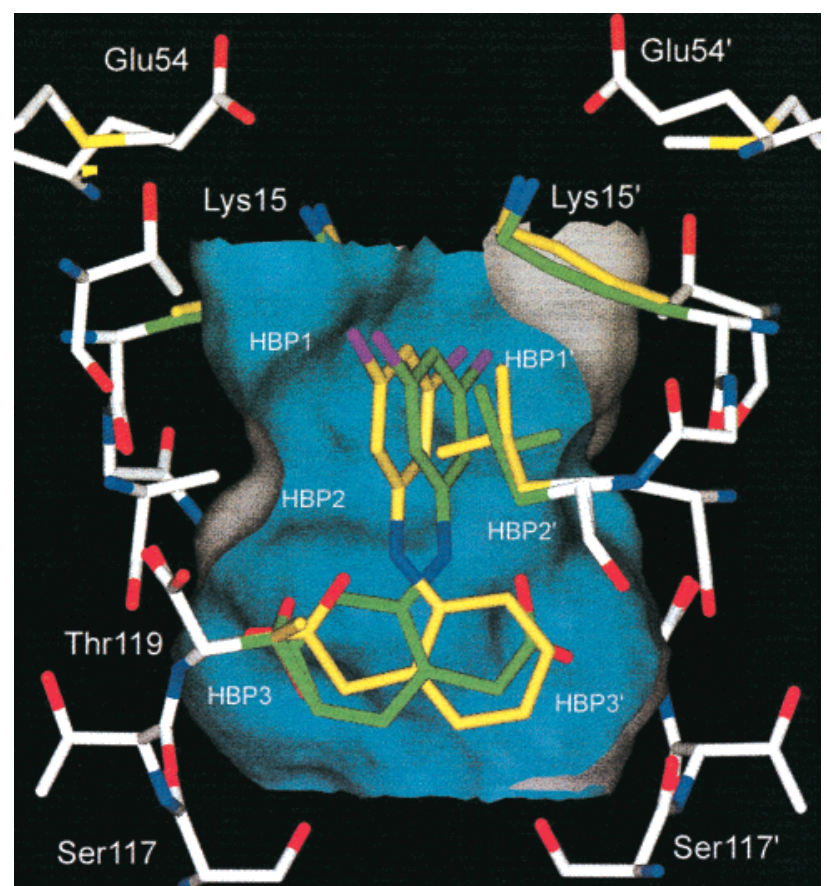

Figure 4. Compound $\mathbf{1 0}$ bound to TTR in two symmetry rel ated binding modes shown in yell ow and green. The surface of the binding site is shown in blue (view from interior) and gray (view from exterior).

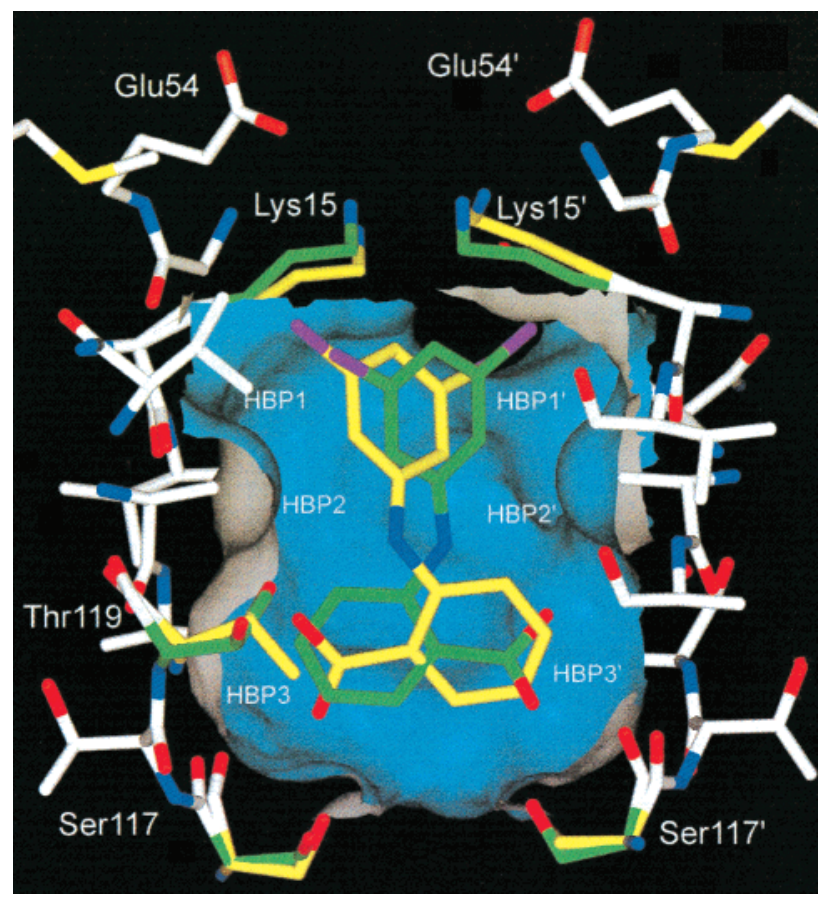

Figure 5. As Figure 4, but with $\mathbf{1 1}$ bound to TTR.

119 in HBP 3. The remainder of the aromatic ring again resides in HBP 3 ' on the other side of the cavity. The 3,5-dichloro substituted ring is less twisted relative to the carboxylic acid bearing ring in $\mathbf{1 1}$ than it is in $\mathbf{1 0}$ or diclofenac (1). This only leads to slight differences in the contacts it makes in the outer cavity. The chlorine atoms still fill HBP 1 and $1^{\prime}$, and the ring still interacts with Lys 15, Leu 17, and Ala 108. Here, though, the interaction with Lys 15 is a van der Waals interaction through the $\epsilon-\mathrm{CH}_{2}$ and the salt bridge between Lys 15 and Glu 54 does not form.

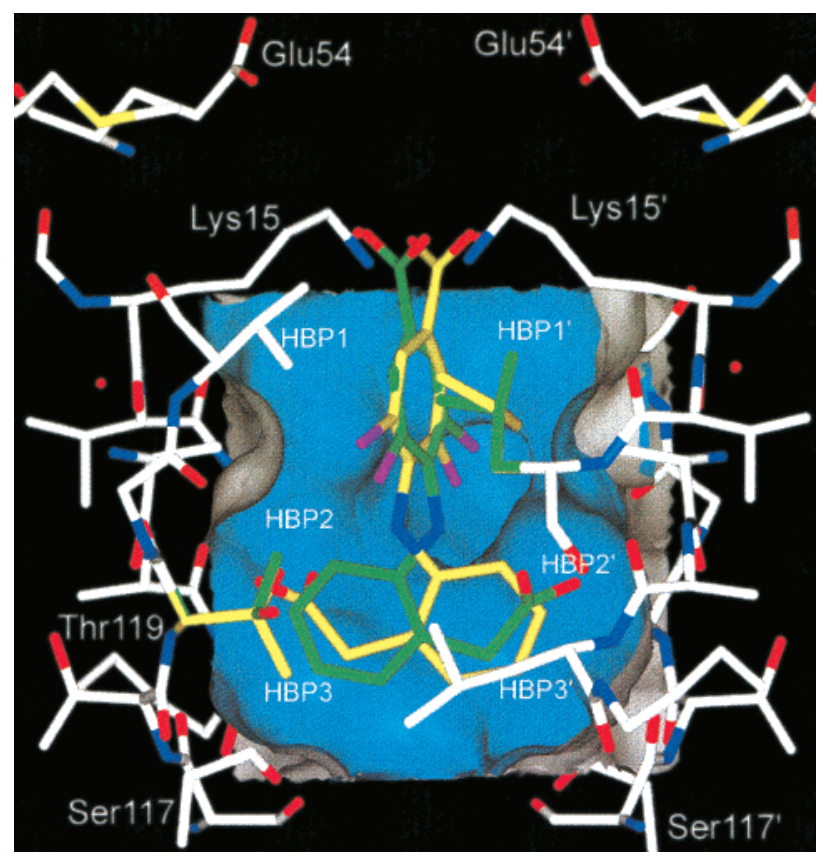

Figure 6. As Figure 4, but with $\mathbf{1 2}$ bound to TTR

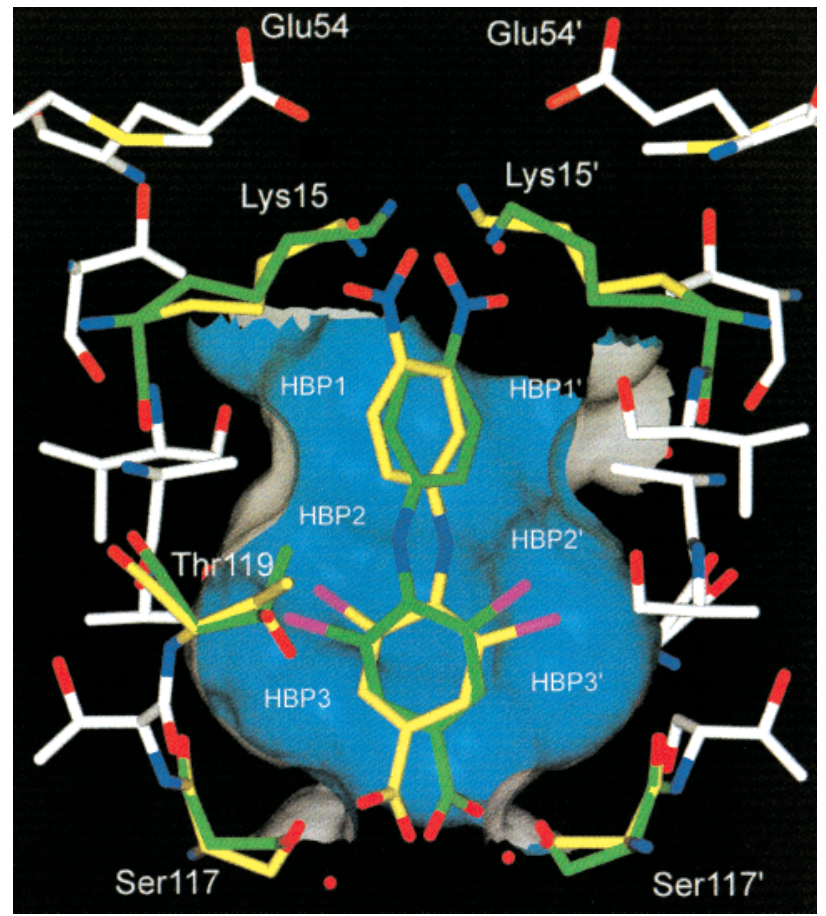

Figure 7. As Figure 4, but with $\mathbf{1 3}$ bound to TTR.

(c) Compound 12 Bound to TTR. The terms "forward" and "reverse" are ambiguous when describing the binding of $\mathbf{1 2}$ to TTR because both of its rings have carboxylate substituents. Its binding can be said to be analogous to that of diclofenac (1) in that its 2-ethanoic acid bearing ring occupies the inner binding cavity, but there are several differences in the details that characterize the binding of $\mathbf{1 2}$ and did ofenac (1). The binding mode shown in yellow in Figure 6 shows that 12 does not reside as deep in the binding site as didlofenac (1). The hydrogen bond between the $\mathrm{COO}^{-}$of $\mathbf{1 2}$ and the $\gamma$-OH of Thr 119 is relatively weak (3.4 $\AA$ O-O distance), and the side chain of Ser 117 is rotated so that its hydroxyl is pointed away from the cavity. It forms a 
van der Waals interaction with $\mathbf{1 2}$, between its $\beta-\mathrm{CH}_{2}$ and the $\mathrm{CH}_{2}$ of the ethanoic acid. The strongest hydrogen bonds between $\mathbf{1 2}$ and TTR occur between the $\mathrm{COO}^{-}$of $\mathbf{1 2}$ and the main chain $\mathrm{NHs}$ of residues Ala 108, Ala 109, and Leu 110. The 2,6-dichloro-4-carboxylic acid substituted ring resides in the outer binding cavity. As with diclofenac (1), the chlorine substituents fill HBP 2 and $2^{\prime}$, which allows the $4-\mathrm{COO}^{-}$to make an additional electrostatic interaction with the $\epsilon-\mathrm{NH}_{3}{ }^{+}$of Lys 15, as intended.

(d) Compound 13 Bound to TTR. Although 13 differs from $\mathbf{1 2}$ only in that it has a $4-\mathrm{NO}_{2}$ aryl ring rather than a 2-ethanoic acid aryl ring, it binds to TTR in an orientation opposite to that of $\mathbf{1 2}$. In the binding mode shown in yellow in Figure 7, $\mathbf{1 3}$ binds with its 2,6-dichloro-4-carboxylic acid substituted ring very deep in the inner cavity. This is accommodated by a rotation of the Thr 119 side chain, which allows the 4-COO ${ }^{-}$to be fairly close to the bottom of the cavity where it can hydrogen bond to the side chain hydroxyl of Ser 117 . The chlorine substituents fill HBP 2 and $2^{\prime}$, just as in dicl ofenac (1) and $\mathbf{1 2}$, except that they are projected into the pockets from the opposite direction; that is, from the inner cavity rather than the outer cavity. The 4- $\mathrm{NO}_{2}$ substituted ring fills the outer binding cavity. The ring itself interacts mainly with the residues of HBP 1 , while the nitro group forms a hydrogen bond with the $\epsilon-\mathrm{NH}_{3}{ }^{+}$ of Lys 15, and a water mediated hydrogen bond with the $\epsilon-\mathrm{NH}_{3}{ }^{+}$of Lys $15^{\prime}$. Note that compound $\mathbf{1 3}$ can also be considered to bind in the reverse mode (although this nomenclature clearly has its limitations), as its $\mathrm{COO}^{-}$ bearing ring binds in the inner cavity.

\section{Discussion}

Structure-Activity Relationships. The relationships between the structures of compounds 2-13 and their fibril inhibition activities against wild type TTR are dominated by the importance of having a negatively charged substituent on one of the rings. This is evident not only from the poor fibril inhibition activities of 6-9, in which the carboxylic acid is replaced by purely hydrophobic groups, but also from the poor fibril inhibition activities of $\mathbf{2 - 4}$, in which the carboxylic acid is replaced by uncharged polar groups. Apparently, it is not sufficient to have a hydrogen bond acceptor in the molecule; compound 4, for example, has an excellent hydrogen bond acceptor in its primary amide, yet it is still only weakly active. A negatively charged substituent is an absolute requirement for high activity in this series of compounds.

While the presence or absence of negative charge has a strong influence on activity, the exact location of the charge does not. High activity is maintained with the charged group attached to the ring via a methylene spacer (as in diclofenac (1) or $\mathbf{1 0}$ ), or with it directly attached (as in $\mathbf{5}$ or 11). F urthermore, having the charge on a separate ring from the chlorines is also not required for activity, as is apparent from $\mathbf{1 3}$ (although it is important for the binding orientation; see below).

The position of the chlorine substituents was expected to be important for fibril inhibition activity since it affects the degree of twist between the two rings of the diarylamine, and degree of twist has been shown to be important to other activities of diclofenac (1) analogues ${ }^{47}$ and $\mathrm{N}$-phenyl anthranilic acids. ${ }^{43}$ However, comparing the activities of didofenac (1) and $\mathbf{5}$, in which the chlorines are in the 2 and 6 positions, to those of $\mathbf{1 0}$ and 11, in which they are in the 3 and 5 positions, reveals that this is not the case. It should be noted that $\mathrm{N}$-phenyl anthranilic acid, the anal ogue of $\mathbf{5}$ and $\mathbf{1 1}$ in which there are no chlorine substituents, has been found to have moderate fibril inhibition activity (\% FF $=51 \%$ at 1 equiv TTR tetramer). ${ }^{27}$ Thus, the presence of the chlorines affects activity, even though variation in their positions is tolerated.

Of the three TTR variants studied, the fibril inhibition activities for $\mathbf{2}-\mathbf{1 3}$ were generally lowest against L55P TTR (consistent with earlier observations ${ }^{24,25,29}$ ), and about the same against V30M and wild type TTR. The structure-activity rel ationships for $\mathbf{2 - 1 3}$ are the same for V30M TTR as they are for wild type TTR, and mostly the same for L55P TTR: a charged functional group is required for high activity in all cases, and the distance of the charge from the ring and the pattern of chlorine substitution can be manipulated without abridging activity. The only notable difference among the different TTR variants is that $\mathbf{1 0}, \mathbf{1 1}$, and $\mathbf{1 2}$ have somewhat higher activities than diclofenac (1) against L55P TTR fibril formation, whereas they have about the same activities as diclofenac (1) against V30M and wild type TTR. In fact, 10, 11, and $\mathbf{1 2}$ are among the most active inhibitors against fibril formation by L55P that have been discovered to date. $24,25,29$ This result is difficult to rationalize because residue 55 is not directly involved in ligand binding, but whatever subtle changes cause the increased amyloidogenicity of L55P TTR may be responsible for the differences observed here

The Reverse Binding Mode. X-ray crystal structures of four of the compounds evaluated herein bound to wild type TTR were solved. Three of these $(\mathbf{1 0}, \mathbf{1 1}$, and 13) are, like diclofenac (1), bound in the reverse mode with their carboxylic acid substituted rings occupying the inner cavity. The remaining compound (12) cannot be said to bind in the reverse mode because both of its rings bear carboxylic acids, yet its mode of binding is clearly analogous to diclofenac's (1) in that its 2-ethanoic acid substituted aryl ring occupies the inner binding cavity. This shows the adaptability of the reverse binding mode in the face of significant structural variation in the ligands. The structures shown in Figures 4-7 provide two reasons for why this binding mode should be so robust. First, there are functional groups capable of making polar interactions all throughout the inner cavity. Ligands that bind deep in the binding site, like 13, can hydrogen bond to the side chain hydroxyl of Ser 117 at the bottom of the cavity; ligands that bind shallow in the binding site, like 12, can hydrogen bond to the main chain at residues 108-110; and ligands that bind between these two extremes, like $\mathbf{1 0}$ and diclofenac (1), can hydrogen bond to the side chain hydroxyl of Thr 119. Second, the three pairs of halogen binding pockets allow ligands to optimize their polar interactions without compromising their van der Waals interactions. This can be demonstrated by comparing the binding of diclofenac (1) to that of 10. Moving the chlorines from the 2 and 6 positions to the 3 and 5 positions causes them to project off the diarylamine scaffold at very different angles in 
didlofenac (1) and $\mathbf{1 0}$, respectively. This is easily accommodated in the binding site by placing the chlorines in HBP1 and $1^{\prime}$ for $\mathbf{1 0}$ instead of HBP2 and $2^{\prime}$ as in diclofenac (1). The chlorine atoms are satisfied while simultaneously allowing the 2-ethanoic acid on the other ring to maintain its interaction with the Thr 119 hydroxyl.

Perhaps the best illustration of the powerful interactions made in the reverse binding mode comes from comparing the cocrystal structures of diclofenac (1), 12, and 13. Adding a 4-carboxylate to the 2,6-dicloro substituted ring in dicl ofenac (1) results in $\mathbf{1 2}$. The effect of this change on the binding is mild. The extra carboxylate is able to satisfy itself by interacting with the $\epsilon-\mathrm{NH}_{3}{ }^{+}$of Lys 15 while the binding orientation remains constant. The 2-ethanoic acid substituted ring still resides in the inner cavity, and the 2,6-dichloro substituted ring still resides in the outer cavity. Eliminating the 2-ethanoic acid in $\mathbf{1 2}$ and adding a 4-nitro group results in $\mathbf{1 3}$. The effect of this change on the binding is drastic. Compound $\mathbf{1 3}$ has only one charged functional group, and it is on the same ring as the chlorine substituents. To maintain the reverse binding mode, the 2,6-dichloro substituted ring occupies the inner cavity, a condition unique to 13 . The advantages of keeping the negatively charged functional group in the inner cavity here seem to outweigh any disadvantages that might have arisen from taking the chlorine substituents out of the outer cavity.

The cocrystal structures of wild type TTR with 1013 show the versatility and strength of the interactions in the reverse binding mode. There is also evidence from previous studies of similar versatility and strength in the forward binding mode. ${ }^{25,30}$ Unfortunately, the systematic variation of the diclofenac (1) structure in this study has yielded only compounds that bind in the reverse mode, leaving no basis for a supposition as to which structural features of diclofenac (1) impart its binding preferences to it. The reasons that flufenamic acid, o-trifluoromethylphenyl anthranilic acid, and flurbi profen bind in the forward mode while dicl ofenac (1) and its analogues bind in the reverse mode remain opaque. However, the ability of TTR to bind ligands in either of two highly adaptable modes provides an explanation for another facet of its binding to small molecules. It has been observed that TTR, like al bumin, is quite promiscuous in its binding to small molecules. The range of structures that are competent as amyloid fibril formation inhibitors has been alluded to above; it has also been found in unrelated studies that TTR binds to aurones, ${ }^{37}$ bi pyridines, ${ }^{35}$ retinoic acid (even without the intermediacy of retinol binding protein), 52 and various organic halogen substances (OHS). ${ }^{34,53-56}$ In fact, it has been suggested that TTR transports polychlorinated biphenyls in vivo. ${ }^{53}$ The exceptional plasticity in the requirements for small molecule binding to TTR probably stems from the existence of two different modes for ligand binding, each of which is able to tolerate significant structural variation.

Outlook for Diclofenac (1) Analogues as Therapeutics for TTR Amyloidosis. Six of the compounds in this study (diclofenac (1), 5, and 10-13) are highly effective as inhibitors of amyloid formation by TTR. However, in order for any of these to serve as thera- peutics for TTR amyloidosis, they must meet two requirements in addition to high activity. First, they must partition into TTR in the presence of all of the other plasma proteins; if they were taken up by other proteins in the blood, then they could not possibly serve to stabilize TTR against amyloid formation during protein turnover. Second, they must have good pharmacological properties, that is, satisfactory bioavailability, half-lives, etc. Data relevant to the first matter have recently been reported. It was found that while dicl ofenac (1) itself did not partition effectively into TTR in human plasma, $\mathbf{1 0}$ and especially $\mathbf{1 1} \mathrm{did} .{ }^{57}$ When $\mathbf{1 0}$ $(10.8 \mu \mathrm{M})$ was added to human plasma, 0.68 equiv of 10 (out of a maximum of 2 equiv) were bound to TTR. Under the same conditions, more than twice as much (1.38 equiv) of $\mathbf{1 1}$ was bound to TTR. ${ }^{57}$ It seems that the exact positions of the chlorine and carboxylic acid substituents are very important to the partitioning into TTR, even though these factors do not strongly affect activity. The second matter will be addressed by testing promising compounds from this study (especially $\mathbf{1 0}$ and 11) in mouse models for TTR amyl oidosis. ${ }^{58}$ The results of these studies will be reported in due course.

\section{Experimental Section}

General Aspects. All glassware was flame dried and cooled under positive argon pressure. All reactions were performed under argon except for the hydrolysis reactions. Reagents and solvents were purchased from Aldrich, Lancaster, Acros, Advanced ChemTech, or Pfaltz-Bauer. THF was dried by passage over $\mathrm{Al}_{2} \mathrm{O}_{3}$, while isopropyl alcohol was distilled from $\mathrm{CaO}$. Other solvents and reagents were used as obtained from the manufacturer. Reactions were monitored by thin-layer chromatography (TLC) on silica gel $60 \mathrm{~F}_{254}$-coated aluminum TLC plates purchased from EM Science. Unless stated otherwise, product purification was performed by flash chromtography using silica gel (230-400 mesh) purchased from EM Science. The purities of new compounds that were essential to the conclusions drawn in the text $(\mathbf{6}, \mathbf{7}, \mathbf{8}, \mathbf{1 2}$, and $\mathbf{1 3})$ were determined by HPLC. Normal phase HPLC was performed with a Waters 600 controller, a Waters 996 photodiode array detector, and a Waters NovaPak Silica col umn. The solvent system was hexanes and ethyl acetate, and gradients were run from 100:0 hexanes:ethyl acetate to 0:100 hexanes:ethyl acetate over $30 \mathrm{~min}$. Reverse phase HPLC was performed with a Waters 600 detector, a Waters 2487 dual wavelength detector, and a Vydac Protein and Peptide C18 column. The solvent system was 95:5 water:acetonitrile $(A)$ and 5:95 water: acetonitrile (B; $A$ and $B$ both have $0.1 \%$ trifluoroacetic acid), and gradients were run from 100:0 A:B to 0:100 A:B over 40 min, then held at $100 \%$ B for $10 \mathrm{~min}$. All HPLC traces are available in the Supporting Information. ${ }^{1} \mathrm{H}$ NMRs were obtained on a Bruker NMR spectrometer at $600 \mathrm{MHz}$, and ${ }^{13} \mathrm{C}$ NMRs were acquired at $150 \mathrm{MHz}$ unless otherwise noted. Chemical shifts are reported in ppm relative to $\mathrm{CDCl}_{3}(7.26$ ppm for ${ }^{1} \mathrm{H}$ NMR and $77 \mathrm{ppm}$ for ${ }^{13} \mathrm{C} N M R$ ) or $\mathrm{CD}_{3} \mathrm{OD}$ (3.31 ppm for ${ }^{1} \mathrm{H} N M R$ and 49.15 ppm for ${ }^{13} \mathrm{C}$ NMR). Mass spectra were obtained at The Scripps Research Institute Center for Mass Spectrometry. The fast atom bombardment (FAB) and MALDI-TOF mass spectra were obtained using NBA/Nal matrix.

Methyl 2-[(2,6-Dichlorophenyl)amino]benzene Acetate (2). To a flame dried round-bottom flask equipped with a stir bar and a rubber septum was added diclofenac (1) (2.96 g, 10 $\mathrm{mmol})$ which was dissolved in methanol $(10 \mathrm{~mL})$ and benzene $(30 \mathrm{~mL})$. The reaction mixture was vented through a bubbler to allow an outlet for the nitrogen produced during the course of the reaction. Trimethylsilyldiazomethane $\left(\mathrm{TMSCHN}_{2}, 2 \mathrm{M}\right.$ solution in hexanes, $7 \mathrm{~mL}, 14 \mathrm{mmols}$ ) was added dropwise to the solution. Upon completion of the addition of $\mathrm{TMSCHN}_{2}$, a yellow color persisted, and the reaction mixture was allowed 
to stir under argon for an additional hour. At the end of this period, the solvent was evaporated yielding a syrup that solidified when dried under vacuum. The crude product thus obtained was purified by flash chromatography using a gradient of EtOAc in hexane (5-40\%) to obtain $2(2.97 \mathrm{~g}, 96 \%) .{ }^{1} \mathrm{H}$ $\operatorname{NMR}\left(\mathrm{CDCl}_{3}\right): \delta 7.98(\mathrm{dd}, \mathrm{J}=7.9,1.8 \mathrm{~Hz}, 1 \mathrm{H}), 7.40(\mathrm{ddd}, \mathrm{J}=$ 7.9, 7.7, $1.3 \mathrm{~Hz}, 1 \mathrm{H}), 7.32(\mathrm{~d}, \mathrm{~J}=7.9 \mathrm{~Hz}, 1 \mathrm{H}), 7.11(\mathrm{~d}, \mathrm{~J}=1.7$ $\mathrm{Hz}, 1 \mathrm{H}), 7.00(\mathrm{dd}, \mathrm{J}=1.7,1.7 \mathrm{~Hz}, 1 \mathrm{H}), 6.85$ (ddd, $\mathrm{J}=7.9,7.4$, $0.8 \mathrm{~Hz}, 1 \mathrm{H}), 3.73(\mathrm{~s}, 2 \mathrm{H}), 3.66(\mathrm{~s}, 3 \mathrm{H}) .{ }^{13} \mathrm{C} N M R\left(\mathrm{CDCl}_{3}\right): \delta$ $168.70,145.73,143.31,135.50,134.24,131.76,122.49,118.98$, 118.84, 115.12, 113.59, 52.02. HRMS: calculated for $\mathrm{C}_{15} \mathrm{H}_{13^{-}}$ $\mathrm{Cl}_{2} \mathrm{NO}_{2} \mathrm{M}^{+}=309.0323$, found 309.0319 .

2-[(2,6-Dichlorophenyl)amino]benzene-ethan-1-ol (3). A round-bottom flask equipped with a magnetic stir bar and a rubber septum was charged with $\mathbf{2}(2.34 \mathrm{~g}, 7.55 \mathrm{mmol})$, which was then dissolved in $15 \mathrm{~mL}$ of THF. The $0.5 \mathrm{M}$ homogeneous solution of $\mathbf{2}$ in THF was cooled to $-22{ }^{\circ} \mathrm{C}$ in a dry ice- $\mathrm{CCl}_{4}$ bath, and $\mathrm{LiAlH}_{4}(0.344 \mathrm{~g}, 9.06 \mathrm{mmol})$ was added in small portions. The reaction mixture was stirred at $-22{ }^{\circ} \mathrm{C}$ for $4 \mathrm{~h}$, after which the dry ice- $\mathrm{CCl}_{4}$ bath was removed, and the reaction mixture was stirred overnight at $25^{\circ} \mathrm{C}$. The reaction was quenched with the dropwise addition of $\mathrm{KHSO}_{4}(10 \%$ in $\mathrm{H}_{2} \mathrm{O}, 25 \mathrm{~mL}$ ) and transferred to a separatory funnel. The product was extracted into the organic layer using EtOAc (3 $\times 50 \mathrm{~mL}$ ). The organic layer was concentrated on a rotary evaporator. Purification of the crude product by flash chromatography using a gradient of EtOAc and hexanes (5-40\%) yielded the desired product $3(0.98 \mathrm{~g}, 46 \%)$ as an off-white solid. ${ }^{1} \mathrm{H}$ NMR $\left(\mathrm{CDCl}_{3}\right): \delta 7.33(\mathrm{~d}, \mathrm{~J}=8.3 \mathrm{~Hz}, 2 \mathrm{H}), 7.19(\mathrm{dd}, \mathrm{J}=$ 7.5, $1.3 \mathrm{~Hz}, 1 \mathrm{H}), 7.08$ (ddd, J = 7.7, 7.7, $1.3 \mathrm{~Hz}, 1 \mathrm{H}$ ), 6.98 (dd, $\mathrm{J}=8.3,7.9 \mathrm{~Hz}, 1 \mathrm{H}), 6.93(\mathrm{dd}, \mathrm{J}=6.6,6.5 \mathrm{~Hz}, 1 \mathrm{H}), 6.48(\mathrm{~d}, \mathrm{~J}$ $=7.4 \mathrm{~Hz}, 1 \mathrm{H}), 4.02(\mathrm{t}, \mathrm{J}=5.7 \mathrm{~Hz}, 2 \mathrm{H}), 3.02(\mathrm{t}, \mathrm{J}=5.6 \mathrm{~Hz}$, $2 \mathrm{H}) .{ }^{13} \mathrm{C} \mathrm{NMR}\left(\mathrm{CDCl}_{3}\right): \delta 142.59,137.66,130.62,129.78$, $129.02,128.86,128.63,126.98,124.03,121.60,116.83,64.22$, 34.77. HRMS: calculated for $\mathrm{C}_{14} \mathrm{H}_{13} \mathrm{Cl}_{2} \mathrm{NO} \mathrm{M}^{+}=281.0374$, found 281.0371.

2-[(2,6-Dichlorophenyl)amino] Benzeneacetamide (4). A round-bottom flask was charged with a stir bar, the sodium salt of diclofenac (1) (Sigma, $318 \mathrm{mg}, 1 \mathrm{mmol}$ ), and PyBop (benzotriazole-1-yl-oxy-tris-pyrrolidino-phosphonium hexafluorophosphate; $520 \mathrm{mg}, 1 \mathrm{mmol}$ ), and capped with a septum. The solvent $\mathrm{CH}_{2} \mathrm{Cl}_{2}$ (10 mL), DIEA (diisopropylethylamine; $391 \mu \mathrm{L}$, $2.25 \mathrm{mmol}$ ), and $30 \%$ aqueous $\mathrm{NH}_{4} \mathrm{OH}(1.3 \mathrm{~mL}, 19.4 \mathrm{mmol})$ were added sequentially to the reaction mixture via syringe through the septum. The reaction mixture was allowed to stir at room temperature for $2 \mathrm{~h}$, then concentrated to dryness on a rotary evaporator and dissolved in EtOAc $(50 \mathrm{~mL})$. The EtOAc layer was washed with brine $(2 \times 20 \mathrm{~mL})$ and dried with $\mathrm{MgSO}_{4}$. The organic layer was concentrated and subjected to flash chromatography using $30 \%$ EtOAc in hexanes to yield $36 \mathrm{mg}(12 \%)$ of 4 as a white solid. ${ }^{1} \mathrm{H}$ NMR $\left(\mathrm{CDCl}_{3}\right): \delta 7.50(\mathrm{~d}$, $\mathrm{J}=7.9 \mathrm{~Hz}, 2 \mathrm{H}), 7.32-7.39(\mathrm{~m}, 2 \mathrm{H}), 7.19-7.21(\mathrm{~m}, 1 \mathrm{H}), 7.08-$ $7.10(\mathrm{~m}, 1 \mathrm{H}), 6.40(\mathrm{~d}, \mathrm{~J}=7.9 \mathrm{~Hz}, 1 \mathrm{H}), 3.77(\mathrm{~s}, 2 \mathrm{H}) .{ }^{13} \mathrm{C} \mathrm{NMR}$ $\left(100 \mathrm{MHz} \mathrm{CDCl}_{3}\right): \delta 173.56,143.21,135.42,130.73,130.34$, $128.97,127.85,124.74,124.21,123.00,109.06,35.66$. HRMS: calculated for $\mathrm{C}_{14} \mathrm{H}_{10} \mathrm{Cl}_{2} \mathrm{NO}$ (loss of $\mathrm{NH}_{2}$ ) $\mathrm{M}^{+}=278.0134$, found 278.0132.

2-[(2,6-Dichlorophenyl)amino]benzoic Acid (5). Prepared as described by Chalmers et al. 42 Melting point: 219$221{ }^{\circ} \mathrm{C}$ (lit. $220-222^{\circ} \mathrm{C}$ ). ${ }^{1} \mathrm{H}$ NMR (DMSO- $\left.\mathrm{d}_{6}\right): \delta 9.55$ (d, J = $7.7 \mathrm{~Hz}, 1 \mathrm{H}), 7.62(\mathrm{~d}, \mathrm{~J}=7.7 \mathrm{~Hz}, 2 \mathrm{H}), 7.32-7.40(\mathrm{~m}, 2 \mathrm{H}), 6.81$ $(\mathrm{t}, \mathrm{J}=7.3 \mathrm{~Hz}, 1 \mathrm{H}), 6.24(\mathrm{~d}, \mathrm{~J}=8.1 \mathrm{~Hz}, 1 \mathrm{H}) .{ }^{13} \mathrm{C} \mathrm{NMR}$ $\left(\mathrm{CDCl}_{3}\right): \delta 170.00,147.01,134.77,134.06,133.42,131.49$, $129.11,128.27,117.44,112.99,111.93$. HRMS: calculated for $\mathrm{C}_{13} \mathrm{H}_{9} \mathrm{Cl}_{2} \mathrm{NO} 2 \mathrm{Na} \mathrm{M}+\mathrm{Na}^{+}=303.9904$, found 303.9903 .

1-Chloro-2-[(2,6-dichlorophenyl)amino]benzene-ethane (6). A round-bottom flask was charged with compound 3 $(0.56 \mathrm{~g}, 2.0 \mathrm{mmol})$, a stir bar, and a rubber septum. Triphenylphosphine $(0.58 \mathrm{~g}, 2.2 \mathrm{mmol}$ ) was added, and the reaction flask was cooled to $0{ }^{\circ} \mathrm{C}$ using an ice water bath. Finally, pyridine ( $2 \mathrm{~mL}, 25 \mathrm{mmol})$ was added slowly followed by $\mathrm{CCl}_{4}(1 \mathrm{~mL}$, $10.4 \mathrm{mmol}$ ). The resulting solution was allowed to warm gradually to room temperature. The reaction mixture was partitioned between water and ethyl acetate $(10: 30 \mathrm{~mL})$, and the organic layer was washed with $1 \mathrm{~N} \mathrm{HCl}(10 \mathrm{~mL}), 10 \%$ $\mathrm{NaHCO}_{3}(10 \mathrm{~mL})$, then brine $(10 \mathrm{~mL})$. The organic layer was dried over anhydrous $\mathrm{Na}_{2} \mathrm{SO}_{4}$, filtered, and concentrated to obtain crude product that was purified by flash chromatography using a gradient of EtOAc in hexanes (5-40\%) to obtain pure 6 as a yellow-white solid. (0.42 g, 70\%). ${ }^{1} \mathrm{H}$ NMR $\left(\mathrm{CDCl}_{3}\right): \delta 7.33(\mathrm{dd}, \mathrm{J}=7.9,0.9 \mathrm{~Hz}, 2 \mathrm{H}), 7.19(\mathrm{~d}, \mathrm{~J}=7.5 \mathrm{~Hz}$, $1 \mathrm{H}), 7.09(\mathrm{dd}, \mathrm{J}=8.8,8.3 \mathrm{~Hz}, 1 \mathrm{H}), 6.97(\mathrm{~m}, 2 \mathrm{H}), 6.50(\mathrm{~d}, \mathrm{~J}=$ $7.9 \mathrm{~Hz}, 1 \mathrm{H}), 5.81(\mathrm{br} \mathrm{s}, 1 \mathrm{H}), 3.87(\mathrm{t}, \mathrm{J}=7.4 \mathrm{~Hz}, 2 \mathrm{H}), 3.21(\mathrm{t}$, $\mathrm{J}=7.4 \mathrm{~Hz}, 2 \mathrm{H}) \cdot{ }^{13} \mathrm{C} \mathrm{NMR}\left(\mathrm{CDCl}_{3}\right): \delta 141.69,137.34,129.70$, $128.81,127.54,127.30,124.39,122.16,117.54,117.52,43.93$, 34.97. HRMS: calculated for $\mathrm{C}_{14} \mathrm{H}_{12} \mathrm{Cl}_{3} \mathrm{~N} \mathrm{M}^{+}=299.0035$, found 299.0033. Normal phase HPLC retention time: 4.3 min; reverse phase: $45.2 \mathrm{~min}$, >99\% pure.

General Procedure for Pd-Mediated Coupling Reactions to Prepare $\mathbf{7}, \mathbf{8}, \mathbf{9}, \mathbf{1 1}, \mathbf{1 3}$. A round-bottom flask equipped with a stir bar and a condenser was charged with an aniline (1 equiv), and $\mathrm{Cs}_{2} \mathrm{CO}_{3}$ (1.4 equiv), $\mathrm{Pd}_{2}(\mathrm{dba})_{3}$ (tris(dibenzylideneacetone)dipalladium (0); $4.5 \mathrm{~mol} \%$ ), Binap (racemic 2,2'-bis(diphenylphosphino)-1,1'-binaphthyl; 3 mol \%) and the appropriate halide or triflate (1.2 equiv) were added in order. Finally, enough toluene to give a $0.5 \mathrm{M}$ solution in the aniline was added through the septum on the condenser via syringe, and the reaction mixture was refluxed under argon for $36 \mathrm{~h}$. The reaction mixture was cool ed and filtered through Celite. The filtrate was concentrated by rotary evaporation and the crude product purified by flash chromatography using a gradient of EtOAc in hexanes (5-40\%) to obtain pure product for which the yield ranged from $47 \%$ to $85 \%$. The methyl ester of $\mathbf{1 1}$ and the ethyl ester of $\mathbf{1 3}$ were hydrolyzed by dissolving them in THF:MeOH: $\mathrm{H}_{2} \mathrm{O}$ (3:1:1) to $0.125 \mathrm{M}$ and then adding 4 equiv of $\mathrm{LiOH}$. The reaction mixture was stirred for $4-12 \mathrm{~h}$ and then acidifed to $\mathrm{pH} 4$ using $1 \mathrm{M} \mathrm{HCl}$. The reaction mixture turned cloudy white at this time, and the product was extracted into ethyl acetate $(3 \times 30 \mathrm{~mL})$. The organic layer was dried over $\mathrm{Na}_{2} \mathrm{SO}_{4}$ (anhydrous) and concentrated on a rotary evaporator to afford a crude solid that was purified by recrystallization from 1:1 EtOAc:MeOH with enough added hexanes to cause precipitation (the final composition was usually around 1:1:10 EtOAc:M $\mathrm{EOH}$ :hexanes) to obtain fluffy white solids in $60-70 \%$ yield.

Characterization for $\mathbf{7}, \mathbf{8}, \mathbf{9}, \mathbf{1 1}$, and $\mathbf{1 3}$ :

2-[(2,6-Dichlorophenyl)amino]benzene-ethane (7). ${ }^{1 \mathrm{H}}$ $\operatorname{NMR}\left(\mathrm{CDCl}_{3}\right)$ : $\delta 7.36(\mathrm{~d}, \mathrm{~J}=8.3 \mathrm{~Hz}, 2 \mathrm{H}), 7.21(\mathrm{dd}, \mathrm{J}=7.4$, $1.3 \mathrm{~Hz}, 1 \mathrm{H}$ ), 7.04 (ddd, J = 7.7, 7.7, 1.8 Hz, 1H), 7.02 (d, J = $8.3 \mathrm{~Hz}, 1 \mathrm{H}), 6.93$ (ddd, J = 7.4, 7.3, $1.3 \mathrm{~Hz}, 1 \mathrm{H}), 6.43(\mathrm{dd}, \mathrm{J}=$ 8.1, $0.9 \mathrm{~Hz}, 1 \mathrm{H}), 2.75(\mathrm{q}, \mathrm{J}=7.5 \mathrm{~Hz}, 2 \mathrm{H}), 1.34(\mathrm{t}, \mathrm{J}=7.9 \mathrm{~Hz}$, $3 \mathrm{H}) .{ }^{13} \mathrm{C} \mathrm{NMR}\left(\mathrm{CDCl}_{3}\right): \delta 131.75,130.39,128.83,128.57$, $126.21,124.61,121.43,115.80,24.40,13.48$. HRMS: calculated for $\mathrm{C}_{14} \mathrm{H}_{13} \mathrm{Cl}_{2} \mathrm{~N} \mathrm{M}^{+}=265.0425$, found 265.0425 . Normal phase HPLC retention time: 3.4 min; reverse phase: $45.1 \mathrm{~min}$, >99\% pure.

2-[(2,6-Dichlorophenyl)amino]benzene-2-methyl-ethane (8). ${ }^{1} \mathrm{H} N M R\left(\mathrm{CDCl}_{3}\right): \delta 7.26(\mathrm{~d}, \mathrm{~J}=8.0 \mathrm{~Hz}, 2 \mathrm{H}), 7.20$ $(\mathrm{dd}, \mathrm{J}=7.5,1.5 \mathrm{~Hz}, 1 \mathrm{H}), 6.90(\mathrm{~m}, 2 \mathrm{H}), 6.38(\mathrm{dd}, \mathrm{J}=7.9,1 \mathrm{~Hz}$, $\mathrm{lH}), 5.60(\mathrm{bs}, 1 \mathrm{H}), 3.21(\mathrm{~m}, 1 \mathrm{H}), 1.275(\mathrm{~d}, \mathrm{~J}=6.8 \mathrm{~Hz}, 6 \mathrm{H}) .{ }^{13} \mathrm{C}$ NMR $\left(\mathrm{CDCl}_{3}\right): \delta 140.28,137.66,136.77,129.99,128.85$, $125.94,125.54,124.26,121.91,116.64,27.71,22.53$. HRMS: calculated for $\mathrm{C}_{15} \mathrm{H}_{15} \mathrm{Cl}_{2} \mathrm{~N} \mathrm{M}^{+}=279.0582$, found 279.0573 . Normal phase HPLC retention time: $3.6 \mathrm{~min}$; reverse phase: $46.3 \mathrm{~min},>99 \%$ pure.

2-[(2,6-Dichlorophenyl)amino]benzene-propane (9). ${ }^{1} \mathrm{H}$ NMR $\left(300 \mathrm{MHz}^{2} \mathrm{CDCl}_{3}\right): \delta 7.38(\mathrm{~d}, \mathrm{~J}=8.1 \mathrm{~Hz}, 2 \mathrm{H})$, $7.21(\mathrm{~d}, \mathrm{~J}=7.2 \mathrm{~Hz}, 1 \mathrm{H}), 7.05(\mathrm{~m}, 2 \mathrm{H}), 6.93(\mathrm{dd}, \mathrm{J}=7.5$, $7.2 \mathrm{~Hz}, 1 \mathrm{H}), 6.45(\mathrm{~d}, \mathrm{~J}=8.1 \mathrm{~Hz}, 1 \mathrm{H}), 5.66(\mathrm{br} \mathrm{s}, 1 \mathrm{H}), 2.72$ $(\mathrm{t}, \mathrm{J}=7.5 \mathrm{~Hz}, 2 \mathrm{H}), 1.78(\mathrm{~m}, 2 \mathrm{H}), 1.06(\mathrm{t}, \mathrm{J}=7.5 \mathrm{~Hz}, 3 \mathrm{H})$. ${ }^{13} \mathrm{C}$ NMR $(75 \mathrm{MHz}): \delta 141.47,137.82,130.91,130.72,130.10$, 129.26, 126.67, 124.95, 121.75, 116.44, 34.08, 22.82, 14.66. LRMS: calculated for $\mathrm{C}_{15} \mathrm{H}_{15} \mathrm{Cl}_{2} \mathrm{~N} \mathrm{M}^{+}=279 / 281 / 283$, found 279/281/283.

2-[(3,5-Dichlorophenyl)amino]benzoic Acid (11). ${ }^{1} \mathrm{H}$ NMR (DMSO-d $\left.\mathrm{d}_{6}\right): \delta 9.56$ (bs, $\left.1 \mathrm{H}\right), 7.93$ (dd, J $=7.9,1.3 \mathrm{~Hz}$, $1 \mathrm{H}), 7.49$ (ddd, J = 7.9, 7.7, $1.7 \mathrm{~Hz}, 1 \mathrm{H}), 7.36(\mathrm{~d}, \mathrm{~J}=8.3 \mathrm{~Hz}$, $1 \mathrm{H}), 7.23(\mathrm{~d}, \mathrm{~J}=1.7 \mathrm{~Hz}, 2 \mathrm{H}), 7.12(\mathrm{~d}, \mathrm{~J}=1.7 \mathrm{~Hz}, 1 \mathrm{H}), 6.96$ 
$(\mathrm{dd}, \mathrm{J}=7.5,7.4 \mathrm{~Hz}, 1 \mathrm{H}) .{ }^{13} \mathrm{C}$ NMR (DMSO- $\left.\mathrm{d}_{6}\right): \delta 179.31$, $154.29,144.75,144.72$, 144.17, 141.93, 130.79, 130.02, 127.31, 126.57, 125.88. HRMS: calculated for $\mathrm{C}_{13} \mathrm{H}_{9} \mathrm{Cl}_{2} \mathrm{NO}_{2} \mathrm{M}^{+}=$ 281.0010, found 281.0018 .

3,5-Dichloro-4-[(4-nitrophenyl)amino]benzoic Acid (13). ${ }^{1} \mathrm{H}-\mathrm{NMR}\left(\mathrm{CDCl}_{3}\right)$ : $\delta 9.39(\mathrm{~s}, 1 \mathrm{H}), 8.06(\mathrm{~d}, J=9.2 \mathrm{~Hz}, 2 \mathrm{H}), 8.03$ $(\mathrm{s}, 2 \mathrm{H}), 6.68(\mathrm{~d}, \mathrm{~J}=9.2 \mathrm{~Hz}, 2 \mathrm{H}) ;{ }^{13} \mathrm{C} \mathrm{NMR}\left(\mathrm{CDCl}_{3}\right): \delta 174.92$, 160.54, 148.86, 148.11, 143.22, 139.97, 139.94, 135.95, 123.49 HRMS: calculated for $\mathrm{C}_{13} \mathrm{H}_{8} \mathrm{Cl}_{2} \mathrm{~N}_{2} \mathrm{O} \mathrm{M} \mathrm{M}^{+}=325.9861$, found 325.9865. Normal phase HPLC retention time: $20.5 \mathrm{~min}$; reverse phase: $37.0 \mathrm{~min},>99 \%$ pure.

General Procedure for UIIman Coupling Reactions To Prepare 10 and 12. A round-bottom flask equipped with a magnetic stirbar and a Dean-Stark trap/condenser was charged with 2-(2-iodo)phenyl-N,N-dimethylacetamide (1 equiv), the appropriately substituted aniline (2.05 equiv), oven baked anhydrous $\mathrm{K}_{2} \mathrm{CO}_{3}$ (0.8 equiv), freshly activated $\mathrm{Cu}$ powder ( 0.53 equiv), and Cul ( 0.053 equiv). Molecular sieves ( $4 \AA$ ) were placed in a Dean-Stark trap filled with toluene. Additional toluene $(10 \mathrm{~mL})$ was added to the reaction flask, which was heated at reflux for $100 \mathrm{~h}$. After cooling, the reaction mixture was filtered through Celite. The filtrate was concentrated, redissolved in ethyl acetate $(30 \mathrm{~mL})$, and washed with water $(10 \mathrm{~mL} \times 2)$. The organic layer was dried (anhydrous $\left.\mathrm{Na}_{2} \mathrm{SO}_{4}\right)$, filtered, and evaporated to a yellowish liquid that was purified by flash chromatography using a gradient of EtOAc in hexanes (5-40\%) giving the N,N-dimethylamide forms of $\mathbf{1 0}$ and $\mathbf{1 2}$ in $95 \%$ and $97 \%$ yields, respectively. These were hydrolyzed by dissolving the amides at $0.16 \mathrm{M}$ in ethanolic $\mathrm{KOH}(0.67 \mathrm{M})$. This solution was refluxed for $10 \mathrm{~h}$, then cooled to room temperature and concentrated to a suspension that was redissolved in $10 \mathrm{~mL}$ of water. The aqueous solution was extracted with ethyl acetate $(3 \times 30 \mathrm{~mL})$ to remove any organic impurities and discarded. The aqueous solution was acidified using $1 \mathrm{~N} \mathrm{HCl}$ and extracted with ethyl acetate $(3 \times 30 \mathrm{~mL})$. The combined organics were dried (anhydrous $\mathrm{Na}_{2} \mathrm{SO}_{4}$ ), filtered, and evaporated to dryness on a rotary evaporator. The product was purified by reverse phase HPLC (in the case of compound 10; gradient: $90: 10 \mathrm{~A}: \mathrm{B}$ to $15: 85 \mathrm{~A}: \mathrm{B}$ over $30 \mathrm{~min}$ where $A$ was $95: 5$ water:MeCN $+0.1 \%$ TFA and $B$ was 5:95 water:MeCN $+0.1 \%$ TFA) or by recrystallization (in the case of compound 12) from 8.5:1:0.5 hexanes:EtOAc:MeOH

2-[(3,5-Dichlorophenyl)amino]benzene Acetic Acid (10). Characterization data for $\mathbf{1 0}$ are given here since the ${ }^{1} \mathrm{H}$ NMR spectrum was measured in a solvent different from that used previously and because the ${ }^{13} \mathrm{C}$ NMR spectrum for $\mathbf{1 0}$ has not been reported. ${ }^{47}{ }^{1} \mathrm{H} N M R\left(\mathrm{CD}_{3} \mathrm{OD}, 300 \mathrm{MHz}\right): \delta 8.03(\mathrm{~s}, 1 \mathrm{H})$, $7.26-7.36(\mathrm{~m}, 2 \mathrm{H}), 7.10-7.25(\mathrm{~m}, 2 \mathrm{H}), 6.77(\mathrm{dd}, \mathrm{J}=1.5,1.4$ $\mathrm{Hz}, 1 \mathrm{H}), 6.63(\mathrm{~d}, \mathrm{~J}=1.8 \mathrm{~Hz}, 2 \mathrm{H}), 3.58(\mathrm{~s}, 2 \mathrm{H}) .{ }^{13} \mathrm{C} N M R$ $\left(\mathrm{CD}_{3} \mathrm{OD}: \mathrm{CDCl}_{3} 1: 1,75 \mathrm{MHz}\right): \delta 172.82,149.24,139.60,134.77$, $132.15,131.22,128.43,125.25,124.90,116.75,112.33,37.06$. HRMS: calculated for $\mathrm{C}_{14} \mathrm{H}_{11} \mathrm{Cl}_{2} \mathrm{NO}_{2} \mathrm{M}^{+}=294.00$, found 294.00 .

2-[(2,6-Dichloro-4-carboxylic acid-phenyl)amino]benzene Acetic Acid (12). ${ }^{1} \mathrm{H}$ NMR $\left(\mathrm{CD}_{3} \mathrm{OD}\right): \delta 7.92(\mathrm{~s}, 2 \mathrm{H})$, $7.68(\mathrm{~s}, 1 \mathrm{H}), 7.26(\mathrm{~d}, \mathrm{~J}=7.0 \mathrm{~Hz}, 1 \mathrm{H}), 7.12(\mathrm{dd}, \mathrm{J}=$ 7.9, 7.4 Hz, 1 H), $6.97(\mathrm{dd}, \mathrm{J}=7.4,7.0 \mathrm{~Hz}, 1 \mathrm{H}), 6.52(\mathrm{~d}$, $\mathrm{J}=7.9 \mathrm{~Hz}, 1 \mathrm{H}), 3.72(\mathrm{~s}, 2 \mathrm{H}) .{ }^{13} \mathrm{C} \mathrm{NMR}\left(\mathrm{CD}_{3} \mathrm{OD}\right): \delta$ $174.37,165.94,142.20,142.11,131.81,130.79,128.31,128.00$, $126.88,123.42,123.36,119.62,38.70$. HRMS: calculated for $\mathrm{C}_{15} \mathrm{H}_{11} \mathrm{Cl}_{2} \mathrm{NO}_{4} \mathrm{M}^{+}=339.0065$, found 339.0053. Normal phase HPLC retention time: 19.2 min; reverse phase: 35.3 min, >98\% pure.

2-(2-I odo)phenyl-N,N-dimethylacetamide. A round-bottom flask was charged with phenyl acetic acid $(0.867 \mathrm{~g}, 3.32$ $\mathrm{mmol})$, dimethylammonium hydrochloride $(0.245 \mathrm{~g}, 3 \mathrm{mmol})$, and HBTU $(1.23 \mathrm{~g}, 3.3 \mathrm{mmol})$. Acetonitrile $(15 \mathrm{~mL})$ was added, followed by DIEA (1.62 $\mathrm{mL}, 9.3 \mathrm{mmol})$, and the resulting solution was stirred under argon for $15 \mathrm{~h}$. The reaction mixture was concentrated to a syrup that was redissolved in EtOAc $(100 \mathrm{~mL})$. The organic layer was washed with $1 \mathrm{~N} \mathrm{HCl}$ (30 $\mathrm{mL}$ ) fol lowed by $10 \% \mathrm{NaHCO}_{3}(30 \mathrm{~mL})$. The organic layer was dried (anhydrous $\mathrm{Na}_{2} \mathrm{SO}_{4}$ ), filtered, and concentrated. Purification of the crude product by flash chromatography using a gradient of EtOAc in hexanes (5-40\%) afforded a colorless oil that solidified to a white solid under high vacuum $(0.82 \mathrm{~g}$, 94\%). ${ }^{1} \mathrm{H} \mathrm{NMR}\left(\mathrm{CDCl}_{3}\right)$ : $\delta 7.83(\mathrm{dd}, \mathrm{J}=8.1,1.3 \mathrm{~Hz}, 1 \mathrm{H}), 7.31$ (ddd, J = 7.5, 7.4, 0.8 Hz, 1H), $7.26(\mathrm{dd}, \mathrm{J}=7.5,1.7 \mathrm{~Hz}, 1 \mathrm{H})$, 6.94 (ddd, J = 7.5, 7.4, $1.7 \mathrm{~Hz}, 1 \mathrm{H}), 3.80(\mathrm{~s}, 2 \mathrm{H}), 3.04(\mathrm{~s}, 3 \mathrm{H})$, $3.01(\mathrm{~s}, 3 \mathrm{H}) .{ }^{13} \mathrm{C} \mathrm{NMR}\left(\mathrm{CDCl}_{3}\right): \delta 170.13,139.32,139.29$, $138.72,129.85,128.48,101.09,45.77,37.66,35.65$.

Stagnant Fibril Formation Assay. The activities of compounds $\mathbf{2}-\mathbf{1 3}$ as inhibitors of TTR fibril formation were ascertained by a stagnant fibril formation assay that has been described previously. 9,24 Briefly, each compound was dried, then weighed, and dissolved to $7.2 \mathrm{mM}$ in spectroscopic grade DMSO to yield a primary stock solution. Secondary stock solutions at $0.72 \mathrm{mM}$ were prepared by a 10-fold dilution of the primary stocks with DMSO. A typical sample for the measurement of fibril inhibition was prepared by micropipetting $5 \mu \mathrm{L}$ of a secondary stock solution into an eppendorf tube and adding $500 \mu \mathrm{L}$ of TTR at $0.4 \mathrm{mg} / \mathrm{mL}$ in $10 \mathrm{mM}$ sodium phosphate, $100 \mathrm{mM} \mathrm{KCl}$, and $1 \mathrm{mM}$ EDTA (pH 7.6). The sample was mixed by vortexing and incubated for $30 \mathrm{~min}$ at $37^{\circ} \mathrm{C}$. The pH was lowered to 4.2 (in the case of wild type) or 5 (in the case of L55P and V30M) using $495 \mu \mathrm{L}$ of acetate buffer (200 mM acetate, $100 \mathrm{mM} \mathrm{KCl}, 1 \mathrm{mM}$ ETDA). The resulting 1 $\mathrm{mL}$ solution was again vortexed and incubated without further agitation for $72 \mathrm{~h}$ at $37^{\circ} \mathrm{C}$. At the end of this period, the tube was vortexed to ensure a uniform suspension, and the turbidity of the suspension at $400 \mathrm{~nm}$ was measured (except in the case of 13, where readings were taken at $600 \mathrm{~nm}$ due to the inhibitor's red shifted absorbance; note that turbidity is equal to the optical density at wavelengths where absorbance is negligible). The ratio of the turbidities of the sample of interest to that of a sample prepared in the same way but lacking any inhibitor multiplied by $100 \%$ gave the percent fibril formation. All assays were performed in triplicate, and all compounds were assayed with wild type, V30M, and L55P TTR (except for 4 and 5, which were not assayed with L55P). All compounds were found to be soluble over the course of the experiment, ensuring that all turbidity was the result of amyloid formation by TTR

Isothermal Titration Calorimetry. Dissociation constants for diclofenac (1) binding to wild type, V30M, and L55P TTR were determined using a Microcal MCS isothermal titration calorimeter (Microcal Inc., Northhampton, MD). A solution of diclofenac (1) at $435 \mu \mathrm{M}$ in $100 \mathrm{mM}$ phosphate with $100 \mathrm{mM} \mathrm{KCl}, 1 \mathrm{mM}$ EDTA, pH 7.6, was prepared (the concentration was determined using $\epsilon_{280}=10400 \mathrm{M}^{-1}$ $\mathrm{cm}^{-1}$, which was determined by measuring the absorbances of solutions with known amounts of dissolved diclofenac (1)). This solution was titrated into an ITC cell containing 21.1, 20.1 , and $20.0 \mu \mathrm{M}$ wild type, V30M, and L55P TTR, respectively. The initial injection of $2 \mu \mathrm{L}$ of diclofenac (1) solution was followed by 36 injections of $8 \mu \mathrm{L}$ each $\left(25^{\circ} \mathrm{C}\right)$. I ntegration of the thermogram after subtraction of blanks yielded a binding isotherm that fit best to a model of two interacting sites exhibiting negative cooperativity. The data were fit by a nonlinear least squares approach with four adjustable parameters, namely, $\mathrm{K}_{1}, \Delta \mathrm{H}_{1}, \mathrm{~K}_{2}$, and $\Delta \mathrm{H}_{2}$ using the ITC data analysis module in ORIGIN version 2.9 provided by Microcal.

Analytical Ultracentrifugation. The mechanism by which 10, 12, and 13 suppress fibril formation by wild type, V30M, and L55P TTR was determined by incubating the protein at $3.6 \mu \mathrm{M}$ for $72 \mathrm{~h}$ under the conditions of the stagnant fibril formation assay in the presence of $10.8 \mu \mathrm{M}$ of the test compounds. Any precipitate that formed under these conditions were removed by centrifugation at $14000 \mathrm{rpm}$. The quaternary structure of the protein that remained in the supernatant was then analyzed using a Beckman XL-I analytical ultracentrifuge. The acquisition and analysis of data was performed as described previously. ${ }^{11,29,59}$

Crystallization and X-ray Data Collection. Crystalsofrecombinant TTR were obtained from protein solutions at 5 $\mathrm{mg} / \mathrm{mL}$ (in $100 \mathrm{mM} \mathrm{KCl}, 100 \mathrm{mM}$ phosphate, $\mathrm{pH}$ 7.4, $1 \mathrm{M}$ ammonium sulfate) equilibrated against $2 \mathrm{M}$ ammonium 
Table 4. Statistics for X-ray Crystal Structures

\begin{tabular}{|c|c|c|c|c|}
\hline & TTR-10 & TTR-11 & TTR-12 & TTR-13 \\
\hline $\begin{array}{l}\text { resolution }(\AA) \\
\text { no. of unique reflctns measd } \\
\text { completeness (\%) (overall/outer shell) } \\
\mathrm{R}_{\text {sym (overall/outer shell) }}\end{array}$ & $\begin{array}{l}30.0-2.1 \\
18358 \\
99.6 / 98.7 \\
0.085 / 0.258\end{array}$ & $\begin{array}{l}30-2.2 \\
15459 \\
88.9 / 91.6 \\
0.039 / 0.252\end{array}$ & $\begin{array}{l}30.0-1.92 \\
17147 \\
88.9 / 93.0 \\
0.06 / 0.23\end{array}$ & $\begin{array}{l}30-2.0 \\
20292 \\
94.3 / 97.7 \\
0.06 / 0.27\end{array}$ \\
\hline \multicolumn{5}{|c|}{ Refinement Statistics } \\
\hline $\begin{array}{l}\text { resolution }(\AA) \\
\text { R-factor/R-free (\%) } \\
\text { RMS deviations }\end{array}$ & $\begin{array}{l}12-2.1 \\
22.66 . / 25.63\end{array}$ & $\begin{array}{l}10-2.2 \\
22.22 / 28.79\end{array}$ & $\begin{array}{l}10-1.95 \\
20.85 / 25.28\end{array}$ & $\begin{array}{l}12-2.0 \\
18.73 / 25.76\end{array}$ \\
\hline $\begin{array}{l}\text { bond length }(\AA) \\
\text { bond angles (deg) }\end{array}$ & $\begin{array}{l}0.010 \\
1.67\end{array}$ & $\begin{array}{l}0.011 \\
1.64\end{array}$ & $\begin{array}{l}0.011 \\
1.54\end{array}$ & $\begin{array}{l}0.011 \\
1.57\end{array}$ \\
\hline
\end{tabular}

sulfate in hanging drop experiments. The TTR-ligand complexes were prepared from crystals soaked for 4 weeks with a 10 -fold molar excess of the ligand to ensure full saturation of both binding sites. For $\mathbf{1 0}$ and $\mathbf{1 1}$, a 1:1 acetone:water solution was used as a soaking agent. A DI P2030 imaging plate system (MAC Science, Yokohama, Japan) coupled to an RU200 rotating anode X-ray generator was used for data collection. The crystals were placed in paratone oil as a cryo-protectant and cooled to $120 \mathrm{~K}$ for our diffraction experiments. Crystals of all TTR-ligand complexes are isomorphous with the apo crystal form with unit cell dimensions $a=43 \AA, b=86 \AA$, and $c=65 \AA$. They belong to the space group $P 2{ }_{1} 2{ }_{1} 2$, and contain half of the homotetramer in the asymmetric unit. Data were reduced with DENZO and SCALEPACK. ${ }^{60}$

Structure Determination and Refinement. The protein atomic coordinates for TTR from the Protein Data Bank (accession number 1BMZ) were used as a starting model for the refinement of native TTR and the TTR-ligand complexes by molecular dynamics and energy minimization using the program CNS. ${ }^{61} \mathrm{~F}$ or the complexes of TTR with 10, 11, 12, and $\mathbf{1 3}$, the resulting maps revealed binding of the ligand in both binding pockets of the TTR tetramer. Using these maps, the ligand could be unambiguously placed into the density and was included in the crystallographic refinement. In all cases the minimum energy conformation of the inhibitor calculated by the program Insight II (Molecular Simulations Inc.) was in good agreement with the initial annealed $\left|F_{o}\right|-\left|F_{d}\right|$ maps for the complex and was used as the initial model in the crystallographic refinement. Because the 2-fold crystallographic symmetry axis is along the binding channel, a statistical disorder model had to be applied, giving rise to two ligand binding modes in each of the two binding sites of tetrameric TTR. After several cycles of simulated annealing and subsequent positional and temperature factor refinement, water molecules were placed into difference Fourier maps. For the four TTR-ligand complexes both symmetry related binding conformations of the ligand were in good agreement with unbiased annealed $2\left|F_{o}\right|-\left|F_{c}\right|$ omit maps, phased in the absence of the inhibitor. Because of the lack of interpretable electron densities in the final map, the nine $\mathrm{N}$-terminal and three C-terminal residues were not included in the final model. A summary of the crystallographic analysis is presented in Table 4.

Acknowledgment. We thank $\mathrm{H}$. Razavi for technical assistance. This work was supported by the $\mathrm{NIH}$ (DK 46335), the Skaggs Institute of Chemical Biology, and the Lita Annenberg Hazen Foundation. V.B.O. thanks the Hereditary Disease Foundation for financial support.

Supporting Information Available: Normal and reverse phase HPLC traces demonstrating the purity of compounds $\mathbf{6}, \mathbf{7}, \mathbf{8}, \mathbf{1 2}$, and $\mathbf{1 3}$. This material is available free of charge via the Internet at http://pubs.acs.org.

\section{References}

(1) Blake, C. C.; Swan, I. D.; Rerat, C.; Berthou, J .; Laurent, A.; Rerat, B. An X-ray study of the subunit structure of preal bumin. J. Mol. Biol. 1971, 61, 217-224.
(2) Blake, C. C.; Geisow, M. J .; Oatley, S. J .; Rerat, B.; Rerat, C. Structure of prealbumin: secondary, tertiary and quaternary interactions determined by Fourier refinement at $1.8 \AA$. J . Mol. Biol. 1978, 121, 339-356.

(3) Bartalena, L.; Robbins, J. Thyroid hormone transport proteins. Clin. Lab. Med. 1993, 13, 583-598.

(4) Aldred, A. R.; Brack, C. M.; Schreiber, G. The cerebral expression of plasma protein genes in different species. Comp. Biochem. Physiol. B Biochem. Mol. Biol. 1995, 111, 1-15.

(5) Schreiber, G.; Richardson, S. J . The evolution of gene expression, structure and function of transthyretin. Comp. Biochem. Physiol. B Biochem. Mol. Biol. 1997, 116, 137-160.

(6) Monaco, H. L. The transthyretin-retinol-binding protein complex. Biochim. Biophys. Acta 2000, 1482, 65-72.

(7) Schreiber, G.; Southwell, B. R.; Richardson, S. J . Hormone delivery systems to the brain-transthyretin. Exp. Clin. Endocrinol. Diabetes 1995, 103, 75-80.

(8) Colon, W.; Kelly, J. W. Partial denaturation of transthyretin is sufficient for amyloid fibril formation in vitro. Biochemistry 1992, $31,8654-8660$.

(9) Lai, Z.; Colon, W.; Kelly, J . W. The acid-mediated denaturation pathway of transthyretin yields a conformational intermediate that can self-assemble into amyloid. Biochemistry 1996, 35, 6470-6482.

(10) Kelly, J. W.; Colon, W.; Lai, Z.; Lashuel, H. A.; McCulloch, J .; McCutchen, S. L.; Miroy, G. J .; Peterson, S. A. Transthyretin quaternary and tertiary structural changes facilitate misassembly into amyloid. Adv. Protein Chem. 1997, 50, 161-181.

(11) Lashuel, H. A.; Lai, Z.; Kelly, J. W. Characterization of the transthyretin acid denaturation pathways by analytical ultracentrifugation: implications for wild-type, V30M, and L55P amyloid fibril formation. Biochemistry 1998, 37, 17851-17864.

(12) Liu, K.; Cho, H. S.; Lashuel, H. A.; Kelly, J. W.; Wemmer, D. E. A glimpse of a possible amyloidogenic intermediate of transthyretin. Nat. Struct. Biol. 2000, 7, 754-757.

(13) Buxbaum, J . N.; Tagoe, C. E. The genetics of the amyloidoses. Annu. Rev. Med. 2000, 51, 543-569.

(14) Plante-Bordeneuve, V.; Said, G. Transthyretin related familial amyloid polyneuropathy. Curr. Opin. Neurol. 2000, 13, 569-573.

(15) McCarthy, R. E., III; Kasper, E. K. A review of the amyloidoses that infiltrate the heart. Clin. Cardiol. 1998, 21, 547-552.

(16) J acobson, D. R.; Pastore, R. D.: Yaghoubian, R.; Kane, I.; Gallo, G.; Buck, F. S.; Buxbaum, J . N. Variant-sequence transthyretin (isoleucine 122) in late-onset cardiac amyloidosis in black Americans. N. Engl. J. Med. 1997, 336, 466-473.

(17) J acobson, D. R.; McF arlin, D. E.; Kane, I.; Buxbaum, J . N Transthyretin Pro55, a variant associated with early-onset, aggressive, diffuse amyloidosis with cardiac and neurologic involvement. Hum. Genet. 1992, 89, 353-356.

(18) Hornberg, A.; Eneqvist, T.; Olofsson, A.; Lundgren, E.; SauerEriksson, A. E. A comparative analysis of 23 structures of the amyloidogenic protein transthyretin. J . Mol. Biol. 2000, 302, 649-669.

(19) McCutchen, S. L.; Colon, W.: Kelly, J. W. Transthyretin mutation Leu-55-Pro significantly alters tetramer stability and increases amyloidogenicity. Biochemistry 1993, 32, 12119-12127.

(20) McCutchen, S. L.; Lai, Z.; Miroy, G. J .; Kelly, J. W.; Colon, W. Comparison of lethal and nonlethal transthyretin variants and their relationship to amyloid disease. Biochemistry 1995, 34, 13527-13536.

(21) Colon, W.; Lai, Z.; McCutchen, S. L.; Miroy, G. J .; Strang, C.; Kelly, J . W. FAP mutations destabilize transthyretin facilitating conformational changes required for amyloid formation. Ciba Found. Symp. 1996, 199, 228-238.

(22) Suhr, O. B.; Herlenius, G.; Friman, S.; Ericzon, B. G. Liver transplantation for hereditary transthyretin amyloidosis. Liver Transpl. 2000, 6, 263-276.

(23) Gambetti, P.; Russo, C. Human brain amyloidoses. Nephrol. Dial. Transplant. 1998, 13, 33-40. 
(24) Miroy, G. J .; Lai, Z.; Lashuel, H. A.; Peterson, S. A.; Strang, C.; Kelly, J. W. Inhibiting transthyretin amyloid fibril formation via protein stabilization. Proc. Natl. Acad. Sci. U.S.A. 1996, 93, 15051-15056

(25) Peterson, S. A.; Klabunde, T.; Lashuel, H. A.; Purkey, H. Sacchettini, J . C.; Kelly, J. W. Inhibiting transthyretin conformational changes that lead to amyloid fibril formation. Proc Natl. Acad. Sci. U.S.A. 1998, 95, 12956-12960.

(26) Baures, P. W.; Peterson, S. A.; Kelly, J . W. Discovering transthyretin amyloid fibril inhibitors by limited screening. Bioorg. Med. Chem. 1998, 6, 1389-1401.

(27) Baures, P. W.; Oza, V. B.; Peterson, S. A.; Kelly, J . W. Synthesis and evaluation of inhibitors of transthyretin amyloid formation based on the nonsteroidal antiinflammatory drug, flufenamic acid. Bioorg. Med. Chem. 1999, 7, 1339-1347.

(28) Oza, V. B.; Petrassi, H. M.; Purkey, H. E.; Kelly, J . W. Synthesis and evaluation of anthranilic acid-based transthyretin amyloid fibril inhibitors. Bioorg. Med. Chem. Lett. 1999, 9, 1-6.

(29) Petrassi, H. M.; Klabunde, T.; Sacchettini, J .; Kelly, J. W. Structure-Based Design of N-Phenyl Phenoxazine Transthyretin Amyloid Fibril Inhibitors. J . Am. Chem. Soc. 2000, 122, 21782192.

(30) Klabunde, T.; Petrassi, H. M.; Oza, V. B.; Raman, P.; Kelly, J W.: Sacchettini, J. C. Rational design of potent human transthyretin amyloid disease inhibitors. Nat. Struct. Biol. 2000, 7 312-321.

(31) Sallmann, A. R. The history of diclofenac. Am. J . Med. 1986 80, 29-33.

(32) Blake, C. C.; Oatley, S. J. Protein-DNA and protein-hormone interactions in prealbumin: a model of the thyroid hormone nuclear receptor? Nature 1977, 268, 115-120.

(33) Wojtczak, A.; Cody, V.; Luft, J . R.; Pangborn, W. Structures of Human Transthyretin Complexed with Thyroxine at $2.0 \AA$ Resolution and 3', 5'-Dinitro-N-acetyl-L-thyronine at $2.2 \AA$ Resolution. Acta Crystallogr. Sect. D 1996, 52, 758-765.

(34) Ghosh, M.; Meerts, I. A.; Cook, A.; Bergman, A.; Brouwer, A. J ohnson, L. N. Structure of human transthyretin complexed with bromophenols: a new mode of binding. Acta Crystallogr. Sect. D 2000, 56, 1085-1095.

(35) Wojtczak, A.; Luft, J . R.; Cody, V. Structural aspects of inotropic bipyridine binding. Crystal structure determination to $1.9 \AA$ of the human serum transthyretin-milrinone complex. J. Biol. Chem. 1993, 268, 6202-6206.

(36) Wojtczak, A.; Luft, J ;; Cody, V. Mechanism of molecular recognition. Structural aspects of 3,3'-diiodo-L- thyronine binding to human serum transthyretin. J. Biol. Chem. 1992, 267, 353-357.

(37) Ciszak, E.; Cody, V.; Luft, J . R. Crystal structure determination at 2.3-Å resolution of human transthyretin-3',5'-dibromo-2',4,4',6tetrahydroxyaurone complex. Proc. Natl. Acad. Sci. U.S.A. 1992, 89, 6644-6648

(38) Abraham, M. H. Scales of solute hydrogen-bonding: their construction and application to physicochemical and biochemical processes. Chem. Soc. Rev. 1993, 22, 73-83.

(39) Sallmann, A.; Pfister, R. Antiinflammatory, analgesic, and antipyretic phenylacetohydroxamic acids. Ger. Offen. De 2144641 1972

(40) Sallmann, A.; Pfister, R. Analgesic, antiphlogistic, and antipyretic $\beta$-(o-anilinophenyl) ethanols. Ger. Offen. De 2007700, 1970

(41) Takesaki, T.; Hasegawa, Y.; Watanabe, T.; Mori, H.; Yanagihara, K. Diphenylamines. J apan. Kokai J p 53007632, 1978

(42) Chalmers, D. K.; Scholz, G. H.; Topliss, D. J .; Kolliniatis, E.; Munro, S. L.; Craik, D. J .; Iskander, M. N.; Stockigt, J. R. Thyroid hormone uptake by hepatocytes: structure-activity relationships of phenylanthranilic acids with inhibitory activity. J. Med. Chem. 1993, 36, 1272-1277.

(43) Duffy, J . C.; Dearden, J . C.; Rostron, C. A QSAR study of antiinflammatory $\mathrm{N}$-arylanthranilic acids. J . Pharm. Pharmacol. 1996, 48, 883-886.

(44) Kaltenbronn, J. S.; Scherrer, R. A.; Short, F. W.; J ones, E. M.; Beatty, H. R.; Saka, M. M.; Winder, C. V.; Wax, J .; Williamson, W. R. Structure-activity relationships in a series of antiinflam- matory $\mathrm{N}$-arylanthranilic acids. Arzneimittelforschung 1983, 33, 621-627.

(45) J uby, P. F.; Hudyma, T. W.; Brown, M. Preparation and antiinflammatory properties of some 5-(2-anilinophenyl)tetrazoles. J. Med. Chem. 1968, 11, 111-116.

(46) Sallmann, A.; Pfister, R. Phenylacetic acids. Ger. Offen. De 1815802, 1969.

(47) Moser, P.; Sallmann, A.; Wiesenberg, I. Synthesis and quantitative structure-activity relationships of dicl ofenac analogues. J. Med. Chem. 1990, 33, 2358-2368.

(48) Pope, A. J .; Richardson, S. K.; Ife, R. J .; Keeling, D. J . Characterisation of the effects of anthranilic and (indanyloxy) acetic acid derivatives on chloride transport in membrane vesicles. Biochim. Biophys. Acta 1991, 1067, 51-63.

(49) Anisuzzaman, A. K. M.; Whistler, R. L. Selective replacement of primary hydroxyl groups in carbohydrates: preparation of some carbohydrate derivatives containing halomethyl groups. Carbohydr. Res. 1978, 61, 511-518.

(50) Wolfe, J . P.; Buchwald, S. L. I mproved functional group compatibility in the palladium-catalyzed amination of aryl bromides. Tetrahedron Lett. 1997, 38, 6359-6362.

(51) Louie, J .; Driver, M. S.; Hamann, B. C.; Hartwig, J . F. PalladiumCatalyzed Amination of Aryl Triflates and I mportance of Triflate Addition Rate. J. Org. Chem. 1997, 62, 1268-1273.

(52) Zanotti, G.; D'Acunto, M. R.; Malpeli, G.; Folli, C.; Berni, R. Crystal structure of the transthyretin-retinoic-acid complex. Eur. J. Biochem. 1995, 234, 563-569.

(53) Brouwer, A.; Morse, D. C.; Lans, M. C.; Schuur, A. G.; Murk, A J .; Klasson-Wehler, E.; Bergman, A.; Visser, T. J . Interactions of persistent environmental organohalogens with the thyroid hormone system: mechanisms and possible consequences for animal and human health. Toxicol. Ind. Health 1998, 14, 5984.

(54) Lans, M. C.; Klasson-Wehler, E.; Willemsen, M.; Meussen, E.; Safe, S.; Brouwer, A. Structure-dependent, competitive interaction of hydroxy-polychlorobiphenyls, -dibenzo-p-dioxins and -dibenzofurans with human transthyretin. Chem. Biol I nteract. 1993, 88, 7-21.

(55) Meerts, I. A.; van Zanden, J . J .; Luijks, E. A.; van LeeuwenBol, I.; Marsh, G.; J akobsson, E.: Bergman, A.; Brouwer, A. Potent competitive interactions of some brominated flame retardants and related compounds with human transthyretin in vitro. Toxicol. Sci. 2000, 56, 95-104.

(56) van den Berg, K. J. Interaction of chlorinated phenols with thyroxine binding sites of human transthyretin, albumin and thyroid binding globulin. Chem. Biol. Interact. 1990, 76, 6375.

(57) Purkey, H. E.; Dorrell, M. I.; Kelly, J . W. Evaluating the binding selectivity of transthyretin amyloid fibril inhibitors in blood plasma. Proc. Natl. Acad. Sci. U.S.A 2001, 98, 5566-5571.

(58) Teng, M. H.; Yin, J . Y.; Vidal, R.; Ghiso, J .; Kumar, A.; Rabenou R.; Shah, A.; J acobson, D. R.; Tagoe, C.; Gallo, G.; Buxbaum, J. Amyloid and nonfibrillar deposits in mice transgenic for wildtype human transthyretin: a possible model for senile systemic amyloidosis. Lab. Invest. 2001, 81, 385-396.

(59) Lashuel, H. A.; Wurth, C.; Woo, L.; Kelly, J. W. The most pathogenic transthyretin variant, L55P, forms amyloid fibrils under acidic conditions and protofilaments under physiological conditions. Biochemistry 1999, 38, 13560-13573.

(60) Otwinowski, Z.; Minor, W. Processing of X-ray diffraction data collected in oscillation mode. Methods Enzymol . 1997, 276, 307326.

(61) Brunger, A. T.; Adams, P. D.; Clore, G. M.; Delano, W. L.; Gros, P.; Grosse-Kunstleve, R. W.; J iang, J . S.; Kuszewski, J .; Nilges, M.; Pannu, N. S.; Read, R. J .; Rice, L. M.; Simonson, T.; Warren G. L. Crystallography \& NMR system: A new software suite for macromolecular structure determination. Acta Crystallogr. Sect. D 1998, 54, 905-921.

J M010257N 